\title{
A Revision of the Genus Coprinus.
}

\author{
BY \\ GEORGE MASSEE, F.L.S., \\ Principal Assistant (Crypiogams), Royal Herbarium, Kew.
}

With Plates X and XI.

THE Fungi constituting the genus Coprimus, as at present understood, were originally included under the collective name of Agaricus, which at one time covered the whole of the gill-bearing Agarics. Persoon ${ }^{1}$ was the first to detect, in the complete deliquescence of the gills at maturity, a feature of sufficient importance to justify the creation of a special section of Agaricus, under the name of Coprimus, for the reception of those species possessing this peculiarity. At a later date Fries ${ }^{2}$ raised Persoon's section to generic rank, retaining the name Coprimus, characterized mainly by the feature indicated by Persoon, the solution of the gills into a dripping, inky liquid at maturity. In reality, this one biological character is the only constant point of distinction between Coprinus and the remainder of the fleshy, putrescent Agaricineae. Morphologically there is only a relative difference; the statement by Fries in his definition of the genus Coprinus, that the trama is obsolete, is not correct; a welldeveloped trama is always present, formed of interlaced septate hyphae, often furnished with vesicular swellings, running parallel with the sides of the gill or lamella, and

${ }^{1}$ Syst. Meth. Fung., p. 395 (I83 I).

2 Epicr. Syst. Mycol., p. 24I (1836-1838).

[Annals of Botany, Vol. X. No. XXXVIII. June, 1896.] 
giving off free ends which bend outwards, and bear the elements of the hymenium, exactly as in other Agarics. Cystidia are present in the hymenium of most species, and are, as a rule, much larger than elsewhere in the Agaricineae. The spores also, as a rule, are relatively large, one Queensland species-Coprinus gigasporous, Massee-having the largest spores of any known Agaric, measuring 28-30 $\times 14-16 \mu$. In Coprinus insignis, Peck, the spores are minutely asperate; in all other known species the epispore is smooth. In systematic works the spores are said to be black; that is, when seen in the mass on a white ground; and under these conditions the statement is approximately correct, being often accompanied by a tinge of purple or brown. When seen by transmitted light the spores are always some shade of brown, varying in the different species from rich burnt-sienna, through umber, to apparent black, when the colouring matter is so dense that the spore is quite opaque. Karsten ${ }^{1}$ has recently broken up the genus Coprinus into several genera, depending mainly on the shade of colour of the spores, as seen by transmitted light; but, like all attempts at classification based on a single character, whatever may be its merits when treating of the species of a limited area, it breaks down when dealing with the entire number of known species; and even in a local flora, the adoption of narrow characters that will not embrace all known species is perhaps a mistake, inasmuch as it cramps the student's knowledge, and leads him to believe that genera and species are much more sharply defined than they are in reality.

Coprinus sclerotigenus, Ellis and Everh., springs singly or in small numbers from a large, irregular, externally black sclerotium. C. tuberosus, Quélet, also originates from a small, black sclerotium; and Brefeld ${ }^{2}$ has shown that a small sclerotium is formed by $C$. stercorarius, Fr. The number of sclerotium-forming species will probably soon be extended, now that attention has been directed to the subject.

${ }^{1}$ Ryssl. Finl. och den Skandinaviska Hattsvampar, I. pp. 526-550 (I879).

2 Bot. Untersuch. iiber Schimmelpilze, Heft III (188 7 ). 
The flesh of the pileus is very thin in all the species of Coprimus, and in many kinds is reduced to such a delicate membrane that Fries considered it to be entirely wanting, and in his latest work ${ }^{1}$ divides the genus into two tribes, founded respectively. on the supposed presence or absence of a cuticle or layer of flesh covering the gills. The species included in the first tribe-Pelliculosi-have a pellicle, and when the pileus becomes upturned and split at maturity, the splitting takes place through the pellicle, between the gills. In the second tribe-Veliformes-the pellicle is supposed by Fries to be absent, but this view will be shown to be a mistaken one; the radiating grooves which appear as the pileus expands are due to the splitting of the gills themselves, commencing at the back and continuing towards the free edge of each gill, owing to the trama offering least resistance, and consequently giving way first during the expansion of the pileus. The hyphae of the trama do not deliquesce during the splitting of the gill, but are torn apart. As already stated, a very thin but continuous layer of flesh is present, covering the surface of the pileus in the members of the tribe Veliformes; the portion nearest the gills consisting of slender septate interwoven hyphae, the free ends of which give origin to a layer of piriform or subglobose cells, closely packed side by side like the palisade-tissue of a leaf, and forming the free surface of the pileus. During expansion the large cells forming the surface of the pileus are torn apart, but persist in a dry condition, and produce the scurfy or furfuraceous appearance presented by the pileus of all the species of the tribe Veliformes during expansion. Fig. ${ }^{2} 5$ is a section through a portion of the pileus of Coprinus plicatilis, Fries, and shows the splitting of the gills, also the scurfy appearance of the pileus, due to the separated large external cells of the pellicle.

There is no trace of a secondary veil present in any known species of Coprinus: hence a true ring or annulus is never 
present on the stem, the structure called the ring in systematic works being, so far as Coprinus is concerned, the free margin of the volva, or basal portion of the primary or universal veil, which, in some of the more highly organized species, breaks away from the lower fixed portion of the volva, and is carried for some distance up the stem during the increase in length of the latter. In some species, as Coprinus Hendersoni, Berk., this structure is situated about half-way up the stem, to which it is attached by its lower margin, and consequently looks much like a true ring formed from the remains of the secondary veil; but it is in reality only the free margin of the volva, the lower portion of which closely embraces the stem, and is of a looser texture than that of the true stem above the margin of the volva. When the stem is thus surrounded for a considerable portion of its length by an adnate volva, it is said to be peronate. This appearance is produced by the increase in length of the stem being due mostly to basal growth, and in the volva growing at the same rate as the stem it closely surrounds; when the volva does not grow at the same rate as the stem, then its free margin only is carried up by the elongating stem, as frequently seen in Coprimus comatus, Fries. This explanation is equally applicable to all Agarics with a peronate stem.

A clear idea of the broad lines of evolution-morphological and physiological-presented by the Agaricineae is necessary to enable the reader to judge of the view put forward respecting the genetic relationship of the genus Coprinus with the remainder of the series.

Morphologically, the lowest and most primitive type of structure met with in the Agaricineae is illustrated by species included in such genera as Marasmius, Pleurotus, and Claudopus, where the pileus is sessile or stemless, and fixed by its back to the substratum, the gills being uppermost and consequently entirely unprotected from the earliest stage of development. In the second type the pileus is furnished with a more or less evident lateral stem, formed by the outgrowth of a point of the margin of the pileus, the gills 
radiating from the stem-like point; such Fungi grow horizontally, and in the most perfect representatives the pileus has reversed the position characteristic of the first group, and we find the gills occupying the under surface, pointing towards the ground. Panus stypticus illustrates this stage of development. In type three, illustrated by the species of Paxillus, we get shadowed in the umbrella-type of structure, so characteristic of the Agaricineae; the stem has crept within the margin of the pileus, at first near to one edge, or excentric; in the higher species originating from the centre of the under surface, or central; the gills always run down the stem for some distance, thinning out into mere lines, and are described as decurrent. In type four, which includes the greatest number of species, the stem is always central, the gills never decurrent, springing from the stem by their entire width-adnate-or more or less cut out behindadnexed-but always touching the stem. In the fifth and highest type of structure, the stem is central, and the gills are so much cut out behind that they are quite free from the stem, as in the genera Pluteus, Amanita, \&c.

From the above it will be seen that there are three leading lines of departure from the primitive type of structure:(I) Turning the hymenium downwards, away from the light; thus securing protection from sun, rain, \&c., until the spores are mature: (2) The acquisition of a central stem; the stem in itself is an advantage in elevating the pileus from the ground, and thus facilitating the dispersion of the spores by wind, \&c.; and its central position renders possible the closely-set radial arrangement of the gills, a plan which secures the greatest possible hymenial or spore-bearing surface with the least expenditure of material: (3) The freedom of the gills from the stem; the advantage of this point is not obvious, at least not to me, but the persistence with which it is carried out in all the highest forms prove it to be of some decided advantage.

Contemporaneously with the above phases of development we find the gradual evolution of the protective structures, 
known respectively as the primary or universal veil, and the secondary veil, which are most perfect in the highest stage, and entirely absent from the lowest.

The Agaricineae do not form a single group having the sequence indicated, but are in reality broken up into four groups or series, each running through the five types of structure already explained. These four groups are characterized by the colour of the spores, as follows : spores blackMelanosporae; spores brown-Ochrosporae; spores pink or salmon-colour-Rhodosporae; and spores white-Leucospore. These four colour-groups form a sequence of development in time, the Melanosporae being the oldest, and the Leucosporae the newest. The evidence in support of this statement is as follows. In the oldest group, omitting Coprinus, which it has hitherto included, the five types of structure are not represented at the present day, types I and 2 being obsolete; the species are few in number and of world-wide distribution; the sporophore is very short-lived, and entirely lacks the differentiation of structure present in the tissues of the higher groups; the primary and secondary veils, when present, are comparatively rudimentary, and the spores are relatively large.

Passing to the newest group in time, the Leucosporae, we find the species more numerous than those of the three older groups added together; and although representatives are met with everywhere, the different sections and genera are highly characteristic of special regions. All the five types of structure have representatives, the simplest types having fewest species; the sporophore in the highest forms is fleshy, and persists for several days, producing spores in succession, thus extending the period of spore-production, and in proportion the extension of the species in space. In some genera the sporophore is corky and persistent, and from analogy with what occurs in other groups of Fungi, as the Polyporeae, may become perennial. The primary and secondary veils are highly developed, and afford complete protection to the hymenium until the spores are mature. 
In certain genera, as Hygrophorus and Russula, we meet with highly differentiated groups or bundles of laticiferous hyphae, containing hyaline or coloured latex, which in some species is sapid, in others intensely hot and acrid. The by-products of metabolism are utilized in the formation of brilliant colours, and bitter or acrid and often poisonous products. The spores as a rule are minute, and thus readily dispersed by wind. The features thus indicated as characteristic of the Leucosporae, appear in a less perfect and pronounced condition in the older groups, Rhodosporae and Ochrosporae.

Finally, there is one feature of primary importance common to the whole of the Agaricineae, excepting the genus Coprinus; namely, the dissemination of the spores by wind, and for the purpose of effecting this object the gills are persistent-not deliquescent at maturity-and the mature spores are liberated as a very fine, dry powder.

\section{AfFinities.}

In the latest scheme of classification, propounded by Saccardo ${ }^{1}$, Coprinus occupies a central place in the Melanosporae. This location, however, is exceedingly unsatisfactory, owing to the much higher standard of the features characterizing Coprimus, as compared with those of the genera with which it is associated. A truer estimate of Coprinus was shown by Fries $^{2}$, who placed it on a level with the genus Agaricus, as interpreted by him.

As before noted, the species of Coprinus differ from the remainder of the Agaricineae in one important biological feature,-the deliquescence of the gills at maturity into a liquid which drips to the ground, carrying the mature spores along with it. This primitive and relatively imperfect mode of spore-dissemination, as compared with the minute, dry, wind-borne spores of the remainder of the Agaricineae, combined with other evidence to be noted later on, indicates

${ }^{1}$ Sylloge Fungorum, Vol. v, p. 1078 (1887).

${ }^{2}$ Hymenomy. Eur., p. 320 (I874). 
that in the genus Coprimus we have, in reality, the remnant of a primitive group of Fungi, from which have descended the entire modern group of Agaricineae having wind-borne spores; and which, on the other hand, can be traced back to the still more primitive, subterranean Fungi which are the common ancestors of the entire group of the Basidiomycetes.

Evidences of the antiquity of Coprinus are-seen in the world-wide distribution of the genus, and the limited area occupied by species; each large mass of land, and also many islands, having a very high percentage of endemic species. As an illustration of this, we may state that there are II 7 known European species, only eighteen of which extend to other countries; and even amongst the European species, a considerable number are restricted to narrow areas. The half-dozen European species having a wide distribution beyond Europe are just those most associated with agriculture, occurring in farm-yards, dung-hills, \&c., and have in all probability accompanied man in his migrations to new countries, whence they are recorded as occurring in similar habitats.

There is no differentiation of the hyphae into a laticiferous system ; an entire absence of clear, bright colours, as also of those acrid and poisonous protective secretions which characterize the members of the higher Agaricineae. Certain species of Coprinus, as C. comains and C. atramentarius, are edible, and amongst the safest and best of edible Fungi, and probably every species is edible, only owing to their ephemeral nature, and the absence of flesh, they do not commend themselves. The primary veil, when present, exhibits a primitive structure, not being sufficiently firm in texture to form a loose, sheathing volva at the base of the stem, and the portion carried upon the pileus usually consists of evanescent squamules, or a cobweb-like layer which soon vanishes. The thin flesh of the pileus, like that of the gills, deliquesces at maturity.

Notwithstanding the primitive simplicity of structure, it is highly probable that the five types of progressive development explained as present in the Agaricineae were also 
originally present in Coprinus, although the two oldest types are obsolete, so far as is known, at the present day.

Throughout this paper, Coprinus has been spoken of as a genus; and from a systematic standpoint it is perhaps best to continue doing so, although its diagnosis, as already stated, is much broader than that of any other modern genus: for example, we have combined species with free and with adnate gills respectively; some species with a distinct universal veil, others without a trace of this structure, \&c.; the only common bond is the deliquescent gills.

The section Melanosporae of modern Agarics is most closely allied to Coprimus, from which it is directly derived; in fact, numerous species belonging to this group differ from Coprinus only in having dry, persistent gills and winddispersed spores. But, as would be expected, we find in the Melanosporae many species in which the gills show a more or less decided tendency to deliquesce; as specific examples may be mentioned, Hypholoma hydrophilus, Bull ; and Agaricus campestris, L., the common mushroom. The genus Psathyrella, in the Melanosporae, is in the sum-total of its characters nearest to Coprinus. In the Ochrosporae the genus Bolbitius approaches Coprinus in the ephemeral nature of its species, and in the partial deliquescence of the gills, but the spores are orange-brown in the mass.

Finally, in the Leucosporae, the genus Hiatula agrees with the simplest forms of Coprimus in the exceedingly thin flesh of the pileus, and in the gills splitting down the back; but the gills remain dry, and the spores are disseminated by wind.

In the descending series, Coprimus joins on to such genera as Montagnites with its three species, two of which are European, the third from Texas: Phellorinia, three species, S. Africa and Mongolia: and Gyrophragmium, one species from S. Africa. The two last-named genera have been located respectively in the Agaricineae and in the Gastromycetes by different authors, indicating that they are near the point of bifurcation of the two groups from the ancient subterranean basidiosporous Fungi. 
It is interesting to note that, while the liquefaction of the elements of the hymenium - trama, basidia, paraphyses-was finally abandoned at a very early stage in the evolution of the Agaricineae, it persisted throughout the entire sequence of development in the parallel group of the Gastromycetes. In the puffballs - Bovista and Lycoperdon-the well-known water-logged condition of the immature Fungus is due to the melting of the hymenial structures, the spores being thus set free in the gleba, and after attaining maturity become dry, and are eventually dispersed by wind; whereas in the highest order, the Phalloideae, a similar deliquescence takes place, the semi-liquid product having a very decided smell and a sweet taste, much appreciated by insects, who greedily consume it along with the very minute spores imbedded in it; thus the feature which proved a failure in the Agaricineae has been an important factor in raising the Phalloideae to their present position as head of the fungal sub-kingdom.

\section{Distribution.}

The genus is cosmopolitan, species being most abundant in temperate regions; at the same time subtropical and tropical regions yield their own peculiar forms. Two common European species, Coprinus fimetarius and $C$. micaceus, are recorded from Siberia. Three species, C. Barbeyi, C. imbricatus, and $C$. jasmundiamus, are peculiar to the Egyptian desert-region, growing on dung on caravan-tracks. Some species grow in absolute darkness, on timber in the shafts of coal-mines, \&c., and very frequently under such conditions assume peculiar and grotesque forms, some of which have needlessly been raised to specific rank. The different sections of the genus, morphologically considered, are not characteristic of any particular region, as in those instances where a sufficient number of species are recorded from any extra-European country, the different types of structure are represented. An apparent exception to this statement is presented by the known distribution of the members constituting the most 
highly organized section of the genus, characterized by the presence of a volva having a distinct free margin. There are twelve such species known, eleven of which are confined to Europe, the twelfth-Coprimus jasmundianus-being restricted to the Egyptian desert-region. Again, the species furnished with a ring or annulus on the stem are most abundant in Europe; but it must be remembered that both volva and ring are very evanescent structures, usually completely disappearing before the Fungus arrives at maturity, and at best are difficult to distinguish with certainty in the case of dried specimens; hence our knowledge of the subject is as yet too incomplete to justify the statement that the most highly organized species are most abundant in Europe; nevertheless, as shown by the following table, Europe has by far the largest percentage of endemic species.

The following arrangement shows the general and relative distribution of the species, the total number of which is 169 .

Europe ; total of species, II 7 ; endemic species, 99.

Asia

I 2 ; $" \quad, \quad 7$.

Africa

I6; ”

9.

Australasia ,"

I7;

America "

45 ;

5 .

31.

The particular country or district in each continent having the greatest number of species is given below:

\begin{tabular}{|c|c|c|c|c|c|}
\hline France ; & tota & $c$ & 70 & & \\
\hline Ceylon & ” & " & 8 ; & " & $"$ \\
\hline S. Africa & $"$ & " & 9; & " & " \\
\hline W. Australia & $"$ & " & 14 ; & $"$ & $"$ \\
\hline U. States & ", & , & 33 ; & " & ", \\
\hline
\end{tabular}

Great Britain follows France with a total of forty-three species, six of which are endemic. The following countries and islands have each one or more endemic species:Abyssinia, Java, New Zealand, India, Bonin Is., Canary Is., Falkland Is., Venezuela, Brazil, Martinique, Cuba, Cayenne, St. Thomas (W. Indies), Tahiti, Tonga Island. 
Coprinus plicatilis, Fries, a small, ephemeral Fungus, having a membranaceous pileus about $\mathrm{I} \cdot 5^{-2} \mathrm{~cm}$. across, when expanded, has the widest range of any known species; being common throughout Europe, also extending to South and West Africa, India, Ceylon, New Zealand, Tasmania, West Australia, United States, Japan, and Behring Straits.

Coprinus comatus, $C$. atramentarius, $C$. niveus, and $C$. ephemerus are also widely distributed.

Fungi belonging to the genus Coprinus are included in the figures of Japanese plants drawn by native artists, but the exact species cannot be determined with certainty.

\section{Habitats.}

Many species grow on dung or on richly manured ground, and are consequently most abundant in pastoral and agricultural districts, where they find a congenial home in farmyards, on dung-hills, \&c. Other species grow on decaying tree-trunks, or at the base of old gate-posts, and similar localities. One species-Coprimus radians-possessing wellmarked characters, has hitherto been met with only on old damp plastered walls, where the mycelium radiates on every side for a distance of $2-4 \mathrm{~cm}$. from the point of attachment. Finally, a Coprinus has, both in this country and on the continent, been found growing on the dressing of wounds, an occurrence no longer possible, thanks to the researches of Sir Joseph Lister.

\section{Classification.}

It may perhaps be considered superfluous to give descriptions of species that have been previously described. The following are my reasons for so doing; and, furthermore, I consider these same reasons applicable in every instance where a genus has not been recently monographed.

Until quite recently many authors have attached primary importance to one special feature in the discrimination of 
species, and in their diagnoses have emphasized this, to the comparative exclusion of other characters. Unfortunately there appears to have been no common agreement as to what constituted a feature of primary importance, hence the difficulty, or often the impossibility, of gaining a clear idea of the sum-total of characters considered necessary for the discrimination of a species at the present day, from the very brief descriptions of the old authors, and unfortunately also of some quite modern ones. A glance at almost any page of Saccardo's Sylloge Fungorum, which is supposed to give the original description of every described species of Fungus, will illustrate my meaning. It will there be seen that whilst the description of one species may not occupy more than two lines, that of the next species may occupy a dozen or more lines. Of these, the first would in all probability prove to lack points absolutely necessary for the certain identification of the intended species; whereas the second, on the other hand, might possibly prove to be a detailed description of an individual, as difficult to interpret correctly as the shorter one. Difficulties of the nature indicated are by no means absent from the descriptions of species, formulated by so many different individuals, and at different periods, in the genus Coprinus.

The following synopsis aims at keeping a certain number of features in view throughout the entire number of species, as follows:-(I) Form of pileus, especially when young ; (2) presence or absence of volva and ring, and nature of universal veil when broken up by expansion of pileus ; (3) mode of attachment of gills; (4) spores; (5) stem-characters. Unfortunately it is very rare to find all these features noticed in existing diagnoses, but in many instances $I$ have been enabled to fill up omissions from examination of authentic or type specimens in the Herbarium of the Royal Gardens, $\mathrm{Kew}$, and also in some cases from type-specimens kindly lent from other collections. 
Key to the species of Coprimus.

Section I.

Volva distinct, with a free margin; ring present or absent. I-I $2^{1}$.

(The volva is in all cases more or less free from the base of the stem, and when the margin of the volva is persistent the ring is absent ; in other words, the ring in all cases, when present, consists of the free margin of the volva, which breaks away, and is often carried away from the base with the elongating stem. No known species of Coprinus has a secondary veil, from which a true ring or annulus is formed.)

* Large; pileus always more than $2 \mathrm{~cm}$. high and wide. I-6.

$\dagger$ Stem white. $I-4$.

†† Stem coloured. 5-6.

** Small; pileus always less than $2 \mathrm{~cm}$. high and wide. 7-I 2.

$\dagger$ Volva entire. 7-10.

$\dagger \dagger$ Volva torn into shreds. II-I 2.

\section{Section II.}

Volva absent, ring present on the stem. I $3^{-25}$.

(The statement that the volva is absent is morphologically inaccurate; it is present, but closely adnate to the stem which elongates much at the basal portion, the ring eventually occupying a more or less median position on the stem, the portion below the ring being in reality sheathed by the delicate volva-or peronate, as it is usually termed. This is sometimes very evident.)

* Large ; pileus $8-15 \mathrm{~cm}$. high. I3-1 7 .

** Small; pileus never exceeding $3 \mathrm{~cm}$. in height. I $8-25$.

1 The figures correspond to the numbers preceding the names of species in the descriptive portion. 
Section III.

Volva and ring absent. Veil practically absent, pileus either glabrous, or with minute innate squamules, especially near the apex. 26-42.

(Usually large ; closely allied to the last section, differing only in the ring being obsolete. Differs from the glabrous group in Section VI in the pileus not splitting along the lines of the gills.)

* Gills attached to the stem. 26-34.

** Gills free. 35-42.

\section{SECTION IV.}

Volva and ring absent; veil very evident-at least in the young state-under the form of a felt-like layer, which breaks up during expansion into irregular patches; cottony; squamulose; fibrillose; or mealy (but not glistening and micaceous). 43-IOI.

(The presence of a universal veil, and the entire absence of volva and ring, characterizes this, the largest section of Coprimus. The presence of a universal veil implies the existence, at some stage, of a volva, but there is no trace of the latter even during a very young stage, hence for convenience it is described as absent, as in many other genera in the Agaricineae.)

* Veil rather thick and felty, breaking up into irregular, more or less persistent, patches during the expansion of the pileus. 43-49.

† Gills attached to the stem. 43-44.

†† Gills free. 45-49.

** Veil breaking up into superficial scales, cottony, or fibrillose. 50-92.

$\dagger$ Gills attached to the stem. 50-68.

$\S$ Pileus whitish or grey. $50-60$.

$\$ \S$ Pileus tawny or brownish. 6I-68.

t† Gills free. 69-92. 
$\S$ Stem glabrous. $69-78$.

$\S \S$ Stem floccose or pulverulent at first. $79-92$. *** Veil formed of white meal or hyaline vesicles (not glistening and micaceous). 93-101.

\section{Section V.}

Volva and ring absent. Pileus covered with glistening, micaceous particles when young. IO2-I IO.

(It is uncertain as to whether traces of a veil are in reality present on the pileus of the species constituting the present section. The glistening particles of oxalate of lime are washed away in rainy weather, leaving the pileus naked.)

* Gills attached to the stem. I02-106.

** Gills free. IO7-IIO.

\section{SECTION VI.}

Volva, ring, and veil entirely absent; flesh exceedingly thin, and the pileus soon becomes radially fissured or split along the lines of the gills; furfuraceous or scurfy, or glabrous. I I I-165.

(The leading character of the present section consists in the radial splitting of the pileus along the lines of the back of the gills during the expansion of the pileus. In all the previous sections, the radial splitting of the pileus takes place along the lines of striation, which are situated between the gills. The furfuraceous or scurfy appearance is not due to the presence of a veil, but is caused by the cells of the thin flesh which are torn apart, and project outwards when the splitting takes place. In those species where the flesh of the pileus is reduced to a mere film, the surface remains glabrous after splitting.)

* Pileus more or less furfuraceous or scurfy. III-I 3 I.

$\dagger$ Gills attached to the stem. II I-I 20.

$\S$ Pileus white. III-II 3 .

$\$ \S$ Pileus coloured. II4-I 20.

†† Gills free. I2I-I 3 I.

$\S$ Stem fibrillose or downy. I2I-I 22.

$\S \S$ Stem glabrous. I23-I3I. 
** Pileus glabrous. ${ }^{2} 32-165$.

$\dagger$ Gills attached to the stem. I $32-145$.

$\S$ Stem downy or pulverulent. I $32-134$.

$\S \S$ Stem glabrous. I $35^{-1} 45$.

t† Gills free. I46-I 57 .

$\S$ Stem downy or pulverulent, I46-148.

$\$ \S$ Stem glabrous. I49-I 57 .

COPRINUS, Fries.

Pileus symmetrical, flesh thin, usually radially striate or grooved, and bearing the remains of the universal veil; stem central, most frequently hollow, in some species volvate and annulate; gills adnate, adnexed, or free, thin, crowded, deliquescing at maturity, trama well developed; basidia clavate or piriform, tetrasporous; spores large, elliptical or irregularly angular, black, often with a tinge of purple or brown when seen in the mass; cystidia numerous.

Coprinus, Persoon, Syst. Meth. Fung., p. 395 (1801); used as a sectional name in the genus Agaricus.

Fries, Epicr. Syst. Mycol., p. 24I (1836-1838).

\section{Section I.}

1. Coprinus sterquilinus, Fries, Epicr. p. 242.

Pileus conic-ovate, then campanulate, coarsely sulcate, silvery-grey, disc tawny and covered with squarrose squamules, $5-7 \mathrm{~cm}$. high; gills free, purplish-black; spores I 8-20 $\times$ I I-I $2 \mu$; stem 9-I $5 \mathrm{~cm}$. high, fibrillose, white, becoming dark coloured when bruised, volva adnate, margin free, sometimes carried up by the elongating stem as a ring.

On dung and manured ground. Britain, France, Germany, Spain, Portugal, Sweden, Belgium.

Distinguished among volvate species by the squamulose disc, and the white stem becoming blackish when bruised.

2. Coprinus solstitialis, Sacc., Syll. Suppl. 3 , no. 498 .

Pileus cylindric-ovate, $2 \cdot 5-3 \mathrm{~cm}$. high and $\mathbf{I} \cdot 5 \mathrm{~cm}$. broad, even, whitish, covered with spreading, overlapping, somewhat concentrically. 
arranged scales, with an unbroken patch at the disc, soon expanding, becoming blackish, coarsely grooved, and up to $5 \mathrm{~cm}$. across; gills free; stem $3^{-6} \mathrm{~cm}$. high, white, base volvate and with a fugacious ring formed by the margin of the volva breaking away.

On sandy ground. Finland.

Allied to C. sterquilinus, differing in being smaller, and in the stem not becoming black when bruised.

3. Coprinus oblectus, Fries, Epicr. p. 243.

Pileus cylindric-ovate, then campanulate, coarsely striate, at first whitish and silky, glabrous, pale tawny, and sprinkled with rose-coloured powder, $3-5 \mathrm{~cm}$. broad; gills free, pinkish, then black with a purple tinge; spores broadly elliptical, I $8 \times$ I I-I $2 \mu$; stem $8-\mathrm{I} 2 \mathrm{~cm}$. long, persistently white, silky, volva with a broad, recurved margin.

On dung, road-scrapings, \&c. England, France.

4. Coprinus jasmundianus, Kalchbr., in Asch. Beitr. Flor. Aeg., 1879, p. 73 .

Pileus conic-ovate, grooved, sordid, flocculose, $4-5 \mathrm{~cm}$. broad; gills linear, black; stem IO-I $2 \mathrm{~cm}$. long, whitish, striate, hollow, base bulbous, volvate.

On the ground on caravan-tracks. Egypt.

5. Coprinus stenocoleus, Lindblad, in Fries, Mon. p. 306.

Pileus cylindrical, then broadly campanulate and umbonate, even, blackish, with white squamules, $5^{-8} \mathrm{~cm}$. across; gills free; stem IO-1 $5 \mathrm{~cm}$. long, slender, pale tawny, more especially upwards, base thickened and closely sheathed by a long volva having the margin free.

On manured ground. Sweden.

6. Coprinus umbrinus, Mass., Grev. Vol. xxi, p. 41. (Figs. I3-14.)

At first entirely enclosed in a white volva; pileus conico-hemispherical, soon almost plane, coarsely sulcate up to the disc, umber, ornamented with patches of the volva, $4-5 \mathrm{~cm}$. across; gills free;

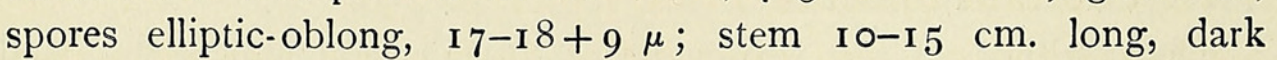
umber from the first, base bulbous, with a persistent white volva having a free, reflexed margin.

On manured ground. England.

Distinguished from $C$. stenocoleus by the sulcate pileus and umber stem. 
7. Coprinus cyclodes, Fries, Epicr. p. 250.

Pileus ovate, then campanulate, striate, glabrous, bay, disc darker, I.5-2 $\mathrm{cm}$. high; stem 4-5 cm. long, 3-4 mm. thick, rather flexuous, white, base sheathed in a volva having a free, recurved margin; gills white, then black.

Gregarious; on horse-dung. Italy, France, Hungary.

8. Coprinus equinus, Chelch., Mem. Phys. de Vars. p. 6, t. xi, f. II.

Pileus ovate, then campanulate, greyish-white, disc darkest, covered with darker scurf and flecks, 3-I $5 \mathrm{~mm}$. broad ; gills free; spores 5-6 and $4-5 \mu$; stem $18-35 \mathrm{~mm}$. long, glabrous, base rather swollen, and enclosed in a volva with a free margin, margin sometimes breaking away as a ring.

On horse-dung. Poland.

9. Coprinus Trappenii, Oudem., Arch. Néerl. ii, p. 29.

Pileus ovate, then campanulate, apex at first bearing fragments of the volva, then glabrous, $\mathbf{I}-\mathbf{I} \cdot 5 \mathrm{~cm}$. across; gills purplish, then black; stem $\mathbf{I}-\mathbf{I} \cdot 5 \mathrm{~cm}$. high, glabrous, base sheathed with a volva, white.

Growing on twigs. Netherlands, Holland.

Distinguished by growing on fallen twigs.

10. Coprinus volvaceo-minimus, Crossl., Grev. Vol. xxi, p. 69.

Pileus ovate, then campanulate, striate, grey, disc darker, sprinkled with white squamules, 4-5 mm. across; gills slightly adnexed; spores 6-7 $\mu$; stem $2-2.5 \mathrm{~cm}$. long, glabrous, hyaline, the bulbous base having a volva with a broad, persistent, free, spreading margin.

On a manure-heap. England.

Distinguished from $C$. Hendersonii by the distinct volva and smaller subglobose spores. May prove to be identical with $C$. bulbillosus, Pat.

\section{Coprinus dilectus, Fries, Epicr. p. $25^{\circ}$.}

Pileus cylindrical, then campanulate, finely striate, rosy-white, then pale tawny, floccose or mealy, $I-2 \mathrm{~cm}$. broad; gills free, reddish brown, then black; stem 5-7 cm. long, whitish and sprinkled with red powder; volva reduced to whitish spreading squamules at the base of the stem.

On scorched ground, in plant-pots, \&c. Sweden, France. 
Agreeing with $C$. oblectus in being sprinkled with red powder, but differing in the finely striate pileus and the much reduced volva.

12. Coprinus panormitanus, Inzenga, Fung. Sicil. ii, p. $5^{8}$, tab. $x$, fig. $I$.

Pileus ovate, white, then grey with an olive tinge, and sprinkled with whitish flecks, even, I.5 $\mathrm{cm}$. high; gills close to the stem; spores ovate, black; stem not longer than pileus, base swollen, rooting, furnished with a torn, ochraceous volva.

On damp ground. Sicily.

Judging from the description and figure, the species was founded on immature, unexpanded specimens.

\section{SECTION II.}

\section{Coprinus comatus, Fries, Epicr. p. 242.}

Pileus cylindrical, then campanulate, whitish or tinged ochraceous, at first even, then becoming broken up into scattered, more or less reflexed, large torn scales, soon becoming campanulate and pinkish grey at the margin, 9-I $5 \mathrm{~cm}$. high; gills very slightly adnexed, pink, then blackish; spores I 2-I $4 \times 8-10 \mu$; stem I2-20 $\mathrm{cm}$. high, stout, white, volva usually evanescent, its free margin forming a ring which is often carried up for some distance by the elongating stem.

Gregarious on rich soil in gardens, pastures, \&c. Britain, Germany, Holland, Spain, Portugal, Denmark, Sweden, France, Italy, Belgium, Russia, Finland, Hungary, Switzerland, Austria, Cape of Good Hope, Himalayas, Japan, Western Australia, Tasmania, New Zealand, United States.

Among the best and safest of edible Fungi.

Var. ovatus, Quél., Enchirid. p. I2I (=Coprinus ovatus, Fries, Epicr. p. 242).

Pileus ovate at first, covered with overlapping, concentrically arranged scales; gills free.

On rich soil, among grass, \&c.

Rather smaller than the type form.

Met with in most countries where the typical form occurs, but not recorded from any country where the type-form is unknown.

Var. clavatus, Quél., Enchirid. p. I 2 I (=Coprinus clavatus, Fries, Epicr. p. 242).

Pileus ovate, soon expanding, surface broken up into shaggy, 
recurved scales, almost from the first; gills free, white, then blackish, without any intermediate red colour; volva without a free margin, hence the ring is absent.

Rather smaller than the type-form.

14. Coprinus atramentarius, Fries, Epicr. p. 243.

Pileus rather fleshy, ovate, then campanulate, irregularly fluted, margin uneven, greyish white, with minute brownish squamules near the apex, 8-I $2 \mathrm{~cm}$. high; gills free, broad, white, then purplish-brown; spores $\mathrm{I} 2 \times 6 \mu$; stem 10-1 $6 \mathrm{~cm}$. long, white, hollow; ring basal, very evanescent.

About old stumps and on rich soil ; not on dung. Britain, France, Germany, Sweden, Italy, Portugal, Holland, Spain, Denmark, Russia, Belgium, Finland, Hungary, Switzerland, Austria, United States, Cape of Good Hope, Kerguelen Island.

Caespitose; large, edible. Distinguished from C. praegnans and C. soboliferus in having the stem distinctly hollow.

15. Coprinus soboliferus, Fries, Epicr. p. 243.

Pileus thin, ovate, then expanded, lower half plicate, disc truncate, often depressed, whitish grey, apex brownish and bearing darker brown squamules, 9-1 $2 \mathrm{~cm}$. high; gills free, broad, white becoming black; spores elliptical, I $5 \times 7 \mu$; stem I $2-20 \mathrm{~cm}$. long, white, stuffed; ring fugacious.

On the ground near trunks and buried wood. Sweden, Britain, Germany, Holland, France, Hungary.

Clustered. Distinguished from allies by the stuffed stem and truncate disc of pileus. Very close to $C$. atramentarius, if indeed distinct as a species.

16. Coprinus pyrenaeus, Quél., Assoc. Franc. ı 887, p. 2, pl. xxi, fig. 6.

Pileus narrowly elliptical, up to $10 \mathrm{~cm}$. long, striate, pearl-grey showing through a dense veil of free white fibrils; gills free, pinkish, then brown; spores irregular, ovoid to almost globose, I 2-1 $8 \mu$ long; stem IO-I $5 \mathrm{~cm}$. long, hollow, white, fibrillose, ring narrow, fugacious, basal.

On the ground in troops in alpine regions. France.

Distinguished from C. atramentarius by the dense white veil.

L 2 
17. Coprinus praegnans, Fries, Epicr. p. 243.

Pileus campanulate, rather fleshy, not striate but everywhere covered with crowded, minute squamules, cinereous; gills free, broad, umber from the first; stem fusiform, rooting, solid, fibrillosely squamulose, ring free.

On the ground. Sweden.

Large, $18-20 \mathrm{~cm}$. high. Allied to C. atramentarius, differing in the gills not being white, then purplish, but umber from the first, solid stem, \&c.

18. Coprinus variegatus, Peck, 25th Rep. New York State Mus. p. 79.

Pileus oblong-ovate, then campanulate, obtuse, hygrophanous, brozon, then whitish, variegated with ochraceous tomentose scales, margin slightly striate, $2 \cdot 5-4 \mathrm{~cm}$. broad; gills free and ascending, white then rosy, at length black; spores elliptical, $9 \mu$ long; stem equal, fragile, hollow, at first peronately-annulate, ring soon disappearing, then floccosely pruinose, $8-\mathrm{r} 3 \mathrm{~cm}$. high.

Among dead leaves. United States.

Distinguished from its ally $C$. atramentarius by being enveloped in a floccose veil when young, which later becomes broken up into scales.

19. Coprinus armillaris, Fries, Nov. Symb. Myc. p. 28.

Pileus pellucid, conical, becoming plane, sulcate, whitish, disc greyish, $2.5 \mathrm{~cm}$. across; gills at first white; stem $5-7.5 \mathrm{~cm}$. long, narrowed upwards from a ventricose base, rufescent and slightly squamulose belowe, with a small, entire, median ring.

Island of St. Thomas, West Indies.

20. Coprinus Hendersonii, Fries, Epicr. p. 250.

Pileus subcylindrical, then almost plane, margin slightly fluted, minutely pruinose, apex tawny, remainder greyish white, up to $\mathbf{I} \mathrm{cm}$. across; gills free; spores elliptic-oblong, I0-1 $2 \times 6 \mu$; stem $3-4 \mathrm{~cm}$. long, with a permanent ring below the middle.

On the ground. Britain, France, Belgium.

There is at times distinct evidence of the stem being peronate up to the ring. Allied to C. bulbillosus, differing in the elliptical spores, and absence of a bulb at base of stem. 
21. Coprinus bulbillosus, Pat., Tab. Anal. Fung., p. 60, fig. 658 .

Pileus convex with the margin striate and incurved, then expanding, grey with the disc tinged yellow, covered with white meal, 8-10 $\mathrm{mm}$ across; gills grey; spores oval, $8-9 \times 6-7 \mu$; stem $2-3 \mathrm{~cm}$. long, slender, white, base bulbous, ring loose, central on the stem.

On horse-dung. France.

Differs from C. Hendersonii in the bulbous stem. C.ephemeroides differs in the squamulose pileus and strigose bulb. See note under C. volvaceo-minimus.

22. Coprinus ephemeroides, Fries, Epicr. p. 250.

Pileus cylindric-ovate, then campanulate, plicato-sulcate, whitish or livid, disc tinged yellow, sprinkled with superficial flecks, up to $\mathbf{I} \mathrm{cm}$. high and broad; gills free, distant from the stem; spores elliptical, I I-I $2 \times 6-7 \mu$; stem $2-4 \mathrm{~cm}$. long, whitish, with a free ring usually placed some distance up the stem, base with a pilose bulb.

On dung. France, Germany, Holland, Sweden, Finland.

Variable in size, but always small and delicate.

Var. muscorum (= Coprinus muscorum, Karsten, Hattsvamp. I,

p. 53 I.

Spores ovoid, $7-9 \times 6-8$, fuscous.

Among dead moss. Finland.

23. Coprinus torquatus, Mont., Cent. vii, no. 29.

Pileus very delicate, soon plane, centre slightly depressed, pellucid, striate up to the even, livid disc, pale grey; gills free and distant from the stem, very narrow ; stem long, slender, base bulbous, ring funnelshaped, entire, whitish.

Solitary. On the ground in damp, shady spots. Brazil.

24. Coprinus scauroides, Godey, in Gillets' Champ. France, Hymen. p. 609.

Pileus ovate, then campanulate, striate, foccosely squamulose, white, then purplish, soon black with the disc yellowish; gills free, purplish, then black; spores ovate, black; stem silvery-white, with a marginate bulb and a ring.

On manured ground. France.

25. Coprinus Bresadolae, Schulz., Hedw. 1885, p. 136.

Pileus subcylindrical, greyish white, apex tinged brown, I $7 \mathrm{~mm}$. high 
by $8 \mathrm{~mm}$. across; gills black, edge white; spores cylindrical, ends rounded, black, $\mathrm{I} 2-\mathrm{I} 7 \times 6 \mu$; stem up to $\mathrm{I} 2 \mathrm{~cm}$. long, base $4 \mathrm{~mm}$. thick, tapering upwards, furnished with a loose, deciduous ring, white, glabrous.

Gregarious; on worked wood. Hungary.

Always expands at night, becoming diffluent as it does so. At first covered with a very thin, universal veil, which does not break up into squamules, but splits from apex to base, and becomes obliterated.

\section{SECTION III.}

\section{Coprinus fuscescens, Fries, Epicr. p. 244.}

Pileus thin, ovate then expanded, striate, margin not lobed, disc rufous, sometimes breaking up into scales, remainder greyish brown, powdered at first with opaque meal, 4-6 cm. high and broad; gills adnexed, narrowed towards the front; spores 8-10 $\times 5^{-6} \mu$; stem 8-I $2 \mathrm{~cm}$. high, fragile, white, hollow, often curved, slightly fibrillose.

On trunks and stumps. Britain, France, Germany, Finland, Holland, Sweden, Belgium, United States, Argentine Republic, Ceylon, Victoria.

Allied to $C$. atramentarius, but smaller, pileus with more of a rufous tinge and not so irregular, and gills gradually narrowing from stem to margin.

27. Coprinus insignis, Peck, 26th Rep. p. 60.

Pileus thin, campanulate, sulcately-striate up to the disc, greyish fawncolour, disc glabrous, sometimes cracking into areolae, $5^{-8} \mathrm{~cm}$. across ; gills ascending; spores asperate, $10 \times 8 \mu$; stem pure white, striate, hollow, IO-I $3 \mathrm{~cm}$. long.

Near roots of trees in woods. United States.

Size and general aspect of $C$. atramentarius, but distinguished from this and all other allies by the rough spores.

28. Coprinus imbricatus, Rabenh., Hedw. I87I, p. 25.

Conic-ovate, then campanulate, white, covered with large, imbricated, concentrically arranged, tawny-white scales, $3.5-5 \mathrm{~cm}$. across; gills adnate and subdecurrent; spores elliptical, I8-2I $\times$ I3-I $4 \mu$; stem white with a tawny tinge, hollow, striate, $5 \mathrm{~cm}$. long.

Among sand. Mesopotamia. 
29. Coprinus Barbeyi, Kalchb., Rev. Mycol. Vol. iii, n. 9o, p. 24, tab. I5, f. I (I88I).

Pileus sub-hemispherical, then expanded, covered with large, persistent, imbricated, pale tawny scales, $2 \cdot 5-5 \mathrm{~cm}$. broad; gills uncinately adnate; spores $\mathbf{I} 3^{-20} \mu \mathrm{long}$; stem about $5 \mathrm{~cm}$. high, hollow, white with a tawny tinge, ending in a dilated disc, below which the mycelium collects the sand and forms an inverted cone.

On camel's dung in sandy desert. Egypt.

This species appears to be identical with $C$. imbricatus, Rab.

30. Coprinus tergiversans, Fries, Epicr. p. 247.

Pileus conical, then expanded, silky, soon grooved, cracked up into minute squamules, rusty brown, disc darker, even, $6-12 \mathrm{~cm}$. broad and high; gills broadly adnate; spores $10 \times 4 \mu$; stem white, equal, glabrous, apex sulcate, $10-14 \mathrm{~cm}$. long.

Caespitose; in rich meadows. Sweden, France, Germany, Holland, Belgium.

Allied to $C$. micaceus, but the pileus is rather more fleshy, darker in colour, and not micaceous, but covered with minute, wart-like squamules.

31. Coprinus Lerchenfeldii, Schulz., Verhandl. Hermann. I 884 , t. I, f. 3 .

Pileus hemispherical, àpex elevated, brownish grey, margin undulated, fimbriate, silvery grey, then violet, $5-7.5 \mathrm{~cm}$. broad; gills violet, shining; stem I 2-1 $5 \mathrm{~cm}$. long, fibrillose, or squamulose.

In gardens. Austria.

32. Coprinus pauci-lamellatus, Pat., Journ. Botanique, I 889 , p. I65.

Pileus thin, campanulato-convex, apex obtuse and squamose, yellowish, remainder white ; margin entire, even; gills few in number $(20-25)$, very distant; spores lemon-shaped, $\mathrm{I}_{5}-20 \times 10-12 \mu$; stem $10-12 \mathrm{~cm}$. long, $5 \mathrm{~mm}$. thick, cylindrical, white, siriate the entire length.

On dung. Venezuela.

33. Coprinus musicola, Berk., Hook. Lond. Journ. Bot. Vol. i, p. 453 .

Pileus companulate, pale purple-brown, surface broken up into squamules, about $\mathbf{I} \cdot 5 \mathrm{~cm}$. high and broad; gills adnexed; spores 
broadly elliptical to subglobose, minutely apiculate, 8-10 $\mu$; stem $2 \cdot 5^{-3} \mathrm{~cm}$. high, slender, pale purple-brown, pulverulent.

On the stem of a Musa. Tahiti.

34. Coprinus fibrillosus, B. \& Br., Linn. Soc. Bot. Journ. Vol. xi, p. 560 .

Pileus ovate, even, grey with persistent fibrillose, darker scales, about I cm. across; gills adnexed, fuscous ; spores elliptical, $5^{-6} \mu$ long; stem $2-3 \mathrm{~cm}$. high, curved, slightly floccose, white.

On the ground. Ceylon.

35. Coprinus cylindricus, Fries, Epicr. p. 244.

Pileus cylindrical, then expanded, rimosely striate, with a few scattered, adpressed squamules, 8-I $2 \mathrm{~cm}$. across when expanded, whitish brown; gills free, rather narrow; stem I $5^{-2}$ I $\mathrm{cm}$. long, equal, fibrillose.

On the ground near trunks. Germany, Sweden.

36. Coprinus Mayrii, Allesch., Sued-bayr. Pilze, p. Io2.

Pileus campanulate, then expanded, white, rather coarsely striate, with small yellow-brown squamules near the margin, disc sparingly scaly, $6-\dot{8} \mathrm{~cm}$. high; gills free, broad, lanceolate; spores $6-7 \times 3^{-4} \mu$; stem $6-8 \mathrm{~cm}$. high, white, striate, base globose, marginate, hollow to the swollen base.

Solitary. On trunks and rotten wood. Bavaria.

Allied to $C$. atramentarius.

37. Coprinus saatiensis, Henn., Engler's Bot. Jahrb., Vol. xiv, p. 352 .

Pileus fleshy, at first cylindric-ovate, covered with imbricated, concentric, white lacerated scales; then expanding, sooty black, variegated with scattered, broad white scales, $5 \mathrm{~cm}$. diameter; gills free; spores I 9-23 $\times$ I0-I $2 \mu$; stem $8 \mathrm{~cm}$. long, I cm. thick, cylindrical, base bulbous, whitish, then tinged fuscous, hollow.

On the ground. Abyssinia.

38. Coprinus punctatus, Kalchbr. \& Cooke, Grev. Vol. ix, p. I8. (Figs. 35-36.)

Pileus cylindrical, then companulate, $2 \cdot 5-3 \cdot 5 \mathrm{~cm}$. broad, brownish, margin striate, apex depressed and squamulose, remainder punctate with minute black squamules and vaguely cracked; gills free, narrowed 
behind; spores $\mathrm{I} 5 \times$ Io $\mu$; stem $\mathrm{I} 5^{-20} \mathrm{~cm}$. long, solid, fibrillose, pallid, ventricose at the middle, base bulbous.

On the ground. Cape of Good Hope.

39. Coprinus flocculosus, Fries, Epicr. p. 245.

Pileus ovate, then expanded, dirty white, striate, with innate squamules, 4-7 cm. across; gills free, narrow; spores $10 \times 7-8 \mu$; stem 6-10 cm. high, white, silky, shining, hollow.

On the ground in fields, \&c. Britain, France, Sweden.

Solitary or tufted. Allied to $C$. aratus and C. lagopus. Differs from the former in the white pileus, and from the latter in the smooth stem and disc of pileus not being brown.

40. Coprinus stenophyllus, Mont., Syll. Plant. Crypt. no. 4IO, p. I32.

Pileus ovoid-campanulate, soon expanded, slightly striate, broken up into scattered ochraceous scales, rufous, becoming fuliginous, $5^{-7} \mathrm{~cm}$. diameter; gills free, but adpressed to the stem, very narrow; stem cartilaginous, elongated, hollow, smooth, white.

On the ground among rotten wood, United States.

Allied to $C$. deliquescens and $C$. micaceus, differing from both in the very narrow gills and scaly pileus.

41. Coprinus microsporus, B. \& Br., Linn. Soc. Journ. (Bot.) Vol. xi, p. 56o. (Fig. 59.)

Pileus campanulate, obtuse, dirty white, with scattered innate, pale umber scales, about $\mathbf{I} \cdot 5 \mathrm{~cm}$. across; gills free, white with a red tinge, slowly becoming black; spores $4-5 \times 2 \mu$; stem $3-4 \mathrm{~cm}$. high, white, smooth, curved, hollow.

On soil. Ceylon.

42. Coprinus macrosporous, Peck, $3^{1 \text { st }}$ Rep. N. York State Mus. p. 35 .

Pileus ovate, then expanded, rimoso-striate, obscurely floccose-squamulose, white, the small, even, brownish disc squamose, $2 \cdot 5-5 \mathrm{~cm}$. across; gills free, white, then black; spores elliptical, $20-25 \times \mathbf{I}_{3}-\mathbf{I} 5 \mu$; stem 5-7.5 cm. high, white, glabrous (with traces of a ring near the thickened base).

Caespitose; ground in open fields. United States.

The prominent characters of this species are the rimose pileus, squamose disc, free gills, and large spores. 


\section{SECTION IV.}

43. Coprinus aphthosus, Fries, Epicr. p. 245.

Pileus ovate, then campanulate, even, livid, at first involved in a continuous white veil, which becomes broken up into superficial, floccose patches, about $2.5 \mathrm{~cm}$. high and broad; gills adnate, spores I 5-I $6 \times$ I० $\mu$; stem about $5 \mathrm{~cm}$. long, white, fibrillose, hollow, soft, often twisted.

In hollow trunks. Britain, Sweden, France.

Growing in small clusters. Differs from $C$. varicus in the hollow, soft stem.

44. Coprinus phaeosporus, Karst., Symb. Myc. Fenn. viii, p. 9, and ix, p. $4^{8}$.

Pileus conico-cylindrical, then flattened, everywhere delicately striate, at first enclosed in a rufescent, floccose veil which breaks up into patches, soon naked and then white, about $2 \mathrm{~cm}$. high ; gills adnexed; spores $9-\mathrm{I} 5 \times 4-9 \mu$; stem $3-\mathrm{I} 2 \mathrm{~cm}$. long, glabrous, white, hollow.

On rich ground at roots of decaying grass. Finland.

Densely caespitose. Distinguished from $C$. albus, Quel., by the pileus not being flocculosely mealy and the glabrous stem.

45. Coprinus picaceus, Fries, Epicr. p. 244.

Pileus ovate, then campanulate, glutinous, striate up to the disc, blackish, at first involved in a white felty layer which becomes broken up into patches as the pileus expands, $4-7 \mathrm{~cm}$. across; gills free; spores $14 \times 8 \mu$; stem IO-I $5 \mathrm{~cm}$. long, white, smooth, hollow, base swollen.

On the ground. Britain, Denmark, France, Italy, Germany, Belgium, Sweden, Spain, Portugal, Queensland, Ecuador, United States.

Distinguished by the black pileus having felt-like white patches scaitered irregularly over its surface.

45*. Coprinus ebulbosus, Peck, Bull. Torrey Bot. Club, Vol. xxii, p. 49 I.

Pileus thin, campanulate, variegated by the cuticle breaking into broad, superficial, persistent, whitish scales, the surface beneath the 
cuticle somewhat striate, greyish brozen, the margin at length revolute, lacerated, $5-7.5 \mathrm{~cm}$. broad; gills narrow, thin, crowded, free, slate colour, becoming black; spores about $10 \times 5.5 \mu$, elliptical, stem 8-I $5 \mathrm{~cm}$. long, 4-6 $\mathrm{mm}$. thick, equal, hollow, white.

Caespitose at the base of cotton-wood stumps. United States.

This plant resembles $C$. picaceus very closely. New York specimens were formerly referred to it as variety ebulbosus, but now having received it from various widely separated localities and finding that it maintains its distinctive character with constancy, it seems best to consider it a good species. Its peculiar characters are the absence of a bulbous base to the stem and its smaller spores. It also sometimes grows in large tufts. 'About fifty grew in a solid clump, all united at the base' (Peck).

If the present plant is so closely allied to Coprinus picaceus, then the structure called the cuticle will in reality be the volva.

\section{Coprinus tomentosus, Fries, Epicr. p. 246.}

Pileus cylindrical, then narrowly conical, at length expanded, striate, entirely covered at first with a greyish felty veil which becomes torn into scales during expansion, pallid or yellowish below the veil, $2 \cdot 5-3 \mathrm{~cm}$. high; gills free; stem about $5 \mathrm{~cm}$. long, velvety, greyish, hollow.

On dung and in rich pastures. Britain, Sweden, Switzerland, Holland, Spain, Portugal, Italy, Russia, Belgium, Finland, France, Germany, Ceylon, Queensland, Kerguelen's Land, Victoria, United States.

47. Coprinus velatus, Quél., Bull. Bot. Soc. Fr., Vol. xxiii, p. 329 , pl. 2, fig. 6 .

Enclosed at first in a thin, white volva; pileus cylindrical, then spreading, coarsely furrowed, yellow or pale ochraceous, $2-3 \mathrm{~cm}$. across; gills free, but close to the stem; spores elliptical, $10 \times 5 \mu$; stem 4-6 cm. long, rather stout, white, villose, coarsely striate.

In troops on the ground in woods. France.

48. Coprinus Forquignoni, Massee.

[Coprinus Quéletii, Forq., Bull. Soc. Bot. France, I887, p. xxxi, pl. I, fig. I (non Schulzer)].

Pileus ellipsoid, then conico-campanulate, at first enclosed in a thickish ochraceous veil, which becomes broken up during expansion 
into irregular, persistent patches, whitish, then tinged grey, $5^{-6} \mathrm{~mm}$. high ; gills free, then remote; spores pip-shaped, $9 \times 6 \mu$; stem up to $5 \mathrm{~mm}$. long, pure white, slightly floccosely-fibrillose, ending in a tawny bulb.

Subgregarious on dead leaves. France.

Distinguished from $C$. Friesii and $C$. tigrinellus by the tawny, furfuraceous bulb at the base of the stem.

49. Coprinus varicus, Fries, Epicr. p. 244.

Pileus ovate, then campanulate, white or livid towards the split margin, covered with broad, irregular, persistent but superficial white patches of the universal veil, $4-5 \mathrm{~cm}$. across; gills free; spores ... ? stem 6-9 cm. long, often incurved, white, glabrous, solid, rigid, tough.

On diseased portions of living beech-trees. Sweden.

Allied to $C$. picaceus, but distinguished by the white pileus and solid, rigid, tough stem.

50. Coprinus niveus, Fries, Epicr. p. 246.

Pileus elliptical, then campanulate, covered with snow-white, floccose down, I. $5^{-2} \cdot 5 \mathrm{~cm}$. across ; gills slightly adnexed; spores $16 \times$ I I-I $3 \mu$; stem villose, white, hollow, 5-8 cm. high.

On dung, especially of horses. Britain, Sweden, France, Germany, Holland, Spain, Portugal, Denmark, Italy, Russia, Belgium, Finland, Hungary, Switzerland, United States, Victoria.

Distinguished by the snow-white colour of every part, the persistently floccose pileus and stem, and adnexed gills.

Var. astroideus, Fries, Epicr. p. 247.

Pileus squamose, then inversed, naked, and grey, about I $2 \mathrm{~mm}$. broad; stem up to $8 \mathrm{~cm}$. long, slender, glabrous, base stellately strigose.

An imperfectly known form.

51. Coprinus Colensoi, Berk., Fl. N. Zeal. ii, p. 175.

Pileus cylindrical, then slightly campanulate, densely covered with persistent white villose down, grey below the down, and delicately striate, 3-4 mm. high; gills adnexed ; spores $7-8 \times 5 \mu$; stem slender, about $2 \mathrm{~cm}$. high, tomentose, white.

On dung. New Zealand.

Resembling $C$. niveus in miniature. 


\section{Genus Coprinus.}

52. Coprinus albus, Quélet, Assoc. France, 1880, p. 4.

Entirely snore-rohite; pileus ovoid, then expanded, floccosely mealy; at length grooved, pearly grey, and with tawny flecks at the summit, up to $2 \mathrm{~cm}$. across; gills adnate, seceding; spores obliquely elliptical, I 2-I $3 \mu$ long; stem coarsely striate upwards, base swollen and downy.

Fasciculate; on decaying vegetable matter, \&c. France.

Superficially resembling $C$. Friesii; allied to $C$. stercorarius.

53. Coprinus pilosus, Beck, Pilzfl. von Niederöst. iii, p. 44.

Pileus at first cylindrical, apex rounded, white, densely covered with septate, acute, hairs, when expanded centre almost glabrous and yellowish, margin slightly striate, $8 \mathrm{~mm}$. broad; gills ...? spores elliptical, $9-\mathrm{I} 2 \times 6-7 \mu$; stem up to $5.5 \mathrm{~cm}$. high, very slender, watery, minutely pubescent, floccose at base.

On sheep-dung. Austria.

54. Coprinus exstinctorius, Fries, Epicr. p. 245.

Pileus cylindric-clavate, then campanulate, margin striate, whitish, apex tinged brown, clothed at first with evanescent, floccose scales, 3-5 cm. across ; gills reaching the stem; spores Io-I I $\times 6-7 \mu$; stem 8-1 $2 \mathrm{~cm}$. long, smooth, white, hollow, swollen at the base and rooting.

On the ground about the roots of trees. Britain, France, Holland, Germany, Sweden, Spain, Portugal, Italy, Russia, Belgium, Ceylon.

Allied to $C$. fimetarius, which differs in the pileus becoming bald from the margin to the disc, whereas the present species becomes bald first at the disc, the baldness progressively extending to the margin.

55. Coprinus fimbriatus, B. \& Br., Linn. Soc. Journ. (Bot.) Vol. xi, p. 561.

Pileus campanulate, tomentose, whitish, margin fringed with white hairs, striate, $\mathbf{I}-2 \mathrm{~cm}$. across; gills adnate; spores $8 \times 5 \mu$; stem $5 \mathrm{~cm}$. long, glabrous, equal, white, hollow.

On dung. Ceylon.

Allied to $C$. stercorarius.

56. Coprinus roris, Quél., Bull. Soc. Bot. Fr., Vol. xxiv, p. 322 , pl. 5 , f. 5 .

Pileus soon convex and with the centre depressed, sulcate, glaucous or pearly grey, covered at first with a thin, evanescent, tawny white veil, 
transparent, $\mathbf{I}-\mathbf{I} \cdot 5 \mathrm{~cm}$. broad; gills adnate; spores ovate, II I-I $2 \mu$ long; stem up to $4 \mathrm{~cm}$. long, slender, greyish, villosely floccose.

Among short grass. France.

Very fugacious, differs from $C$. plicatilis in the adnate gills, and from $C$. diaphanus in the villosely floccose stem.

57. Coprinus Brassicae, Peck, 43rd Rep. N. York State Mus. p. I8, pl. 2, fig. 9-14.

Pileus ovate or conical, then broadly convex, squamulose, finely striate to the disc, white, becoming greyish brown, 4-5 lines broad; gills narrow, reaching the stem, brownish; spores elliptical, brown, $7.5 \times 5 \mu$; stem white, slender, hollow.

On decaying cabbage-stems. United States.

This species is easily known by its squamulose pileus, and its brown gills and spores. Allied to Coprinus phaeosporus, C. Friesï, and C. tigrinellus.

58. Coprinus similis, B. \& Br., Ann. Nat. Hist. Ser. 3, Vol. xv, p. 317 .

Pileus ovate, then campanulate, striate pallid, disc darker, studded with brown-tipped pointed warts which eventually disappear, about $2.5 \mathrm{~cm}$. across ; gills adnate; spores ... ? ; stem white, hollow.

On trunks of dead trees. Britain.

Resembling $C$. aphthosus, but differing in the striate pileus.

59. Coprinus murinus, Kalchbr., Grev. Vol. viii, p. I52, pl. I42, Fig. Io, in Vol. ix.

Pileus conico-campanulate, prominently papillate, sprinkled with white floccose squamules, scarcely striate, grey, up to I $\mathrm{cm}$. high; gills adnexed; stem $\mathbf{I}-3 \mathrm{~cm}$. long, white.

On the ground. Victoria.

Allied to $C$. cooppertus, differing in being papillate, opaque, pulverulent, and not micaceous.

60. Coprinus Brunandii, Quél., Champ. Jura et Vosg. Suppl. xvii, p. 4, t. I 5, f. I I.

Pileus campanulate, 5-6 $\mathrm{mm}$. high, very delicate, striate, greyish lilac, covered at first with very delicate, crystalline, interwoven, caducous 
filaments, 3-4 $\mathrm{mm}$. long; gills adnate, becoming free; stem slender, white, floccose, hollow, bulbous; spores Io $\mu$ long.

Gregarious on rotten leaves in damp places. France.

Allied to C. lagopus.

61. Coprinus domesticus, Fries, Epicr. p. 25I.

Pileus ovate, then campanulate, obtuse, sulcate, disc even, bay, remainder whitish or pale tawny, furfuraceo-floccose, $4-7 \mathrm{~cm}$. across; gills adnexed; spores elliptic-oblong, II I-I $2 \times 7 \mu$; stem $6-9 \mathrm{~cm}$. long, adpressedly silky, white.

On the ground among rubbish, \&c. Britain, Germany, Sweden, France, Russia, Belgium, Switzerland, United States.

Very brittle, often caespitose. Larger than its allies, C. stercoreus, C. ephemerus, \&c.

61*. Coprinus laniger, Peck, Bull. Torr. Bot. Club. Vol. xxii, p. 49I.

Pileus thin, conical or campanulate, covered when young with numerous tawny tomentose or floccose scales, which partly or wholly disappear with age, sulcate-striate nearly to the apex, pallid, tawny or greyish ochraceous, $\mathrm{I}-2.5 \mathrm{~cm}$. across; gills crowded, whitish, then brownish-black; spores oblong-elliptical, $10 \times 4.5 \mu$; stem about $2.5 \mathrm{~cm}$. long, 2-4 mm. thick, slightly thickened at the base, minutely downy or pruinose, white, hollow.

Caespitose at the base of cotton-wood stumps. United States.

The species resembles $C$. micaceus, from which it is distinguishable by the floccose-squamose coating of the young pileus, and by its more narrow spores (Peck).

Unfortunately the author has not observed, or at least not recorded, the attachment of the gills, hence the section to which the present species belong is uncertain. It cannot go into the section containing C. micaceus on account of its floccose veil.

\section{Coprinus alopecia, Fries, Epicr. p. 248.}

Pileus ovate, then campanulate, obtuse, sulcate, at first covered with adpressed fibrils, soon glabrous, pale brown or ochraceous, up to $7.5 \mathrm{~cm}$. broad; gills adnexed; spores ... ? stem at first short, thin, 9-1 $2 \mathrm{~cm}$. long, densely scaly, hollow, base thickened. 
On trunks of oaks and poplars. Sweden, Germany, France.

Caespitose; margin at first undulately plicate, then split and revolute.

63. Coprinus Boudieri, Quél., Bull. Soc. Bot. France, Vol. xxiv, p. 32 I, pl. 5 , f. 4 .

Ovoid, then campanulate, coarsely striate, pale tawny, apex darker, covered with a fine white pubescence, $\mathbf{I}-2 \mathrm{~cm}$. across ; gills adnate; spores angularly globose, IO-I $2 \mu$; stem $3-4 \mathrm{~cm}$. long, white, pruinose and pubescent.

On charcoal-beds. France, Finland.

64. Coprinus Seymouri, Peck, 28th Rep. State Mus. N. York, p. 49.

Caespitose, fragile ; pileus thin, soon expanded, smooth or sprinkled with small, granular scales, dark brown, disc sometimes with a reddish tinge, strongly striate, $\mathbf{I} \cdot 5^{-2.5} \mathrm{~cm}$. broad; gills reaching the stem; spores broadly ovate, compressed, $6-8 \times 5^{-6 \mu}$; stem 7-10 cm. long, white, smooth or slightly pulverulent, equal, hollow.

On clay soil. United States.

Allied to C. micaceus, but thinner, more fragile, darker in colour, and narrower gills.

65. Coprinus discipes, Pat., Journ. Botanique, I 889, p. 339.

Pileus thin, convexo-plane, entirely covered with slender, longitudinal wrinkles, blackish brown, villosely furfuraceous, $\mathbf{I} \cdot 5 \mathrm{~cm}$. across; gills adnate; spores $8-10 \times 6 \mu$; stem about $3 \mathrm{~cm}$. long, cylindrical, springing from a yellow, downy, mycelial disc.

On horse-dung. Martinique.

66. Coprinus subcoeruleo-griseus, Schulzer, Verhandl. Zool. Bot. Gesell. Wien, Band 28, p. 43I.

Pileus very delicate, acutely conical, then plane, slightly striate, disc pale yellowish pink, remainder greyish blue, scattered with minute fugacious scales, $\mathrm{x} \cdot 5^{-2} \mathrm{~cm}$. high and broad; gills adnexed; spores 10-1 $3 \times 6-8 \mu$; stem $3-4 \mathrm{~cm}$. long, white, pruinosely floccose, then glabrous, hollow.

On horse-dung; gregarious. Austria. 
67. Coprinus macropus, B. \& Br., Linn. Soc. Journ. (Bot.), Vol. xi, p. 56o. (Fig. 4I).

Pileus conical, then campanulate, finely striate, browon, at first covered with evanescent, white flecks, 6-8 cm. across; gills adnexed, brown; stem up to $15 \mathrm{~cm}$. long, equal, white, glabrous, rather rooting, hollow.

On the ground. Ceylon.

68. Coprinus virgineus, Peck \& Banning, 44th Rep, N. York State Mus. p. 7I.

Pileus ovate, campanulate or cylindrical, pale ochre, margin thin, torn, floccose; gills adnexed, forked; spores black; stem 8-9 cm. long, stout, flattened, floccose, stuffed.

Caespitose or gregarious at the roots of trees or about old stumps. United States.

68*. Coprinus gigasporus, Massee (sp. nov.) (Figs. 3-5.)

Pileus elliptical, then campanulate, finally upturned, flesh thin, entirely black, at first with a sprinkling of white squamules, finely striate up to the disc, $5-6 \mathrm{~cm}$. high ; gills free, rather distant from the stem, black; spores elliptical, ends obtuse, black, 28-30 $\times$ I 4-1 $6 \mu$; stem I 2-I $7 \mathrm{~cm}$. long, snow-white, equal, hollow.

On dung. Brisbane, Queensland (Bailey, No. 692).

This specimen was referred by Dr. Cooke to Coprinus picaceus, from which it differs in the nature of the veil, free gills, distant from the stem, and gigantic spores, which are the largest produced by any member of the Agaricineae.

69. Coprinus nycthemerus, Fries, Epicr. p. $25 \mathrm{I}$.

Pileus conico-cylindrical, then expanded, plicate, ribs forked at the margin, floccosely mealy, then naked, grey, disc tawny, $\mathbf{I} \cdot 5^{-2} \mathrm{~cm}$. broad; gills free; stem $5^{-7} \mathrm{~cm}$. long, white, glabrous, flaccid, hollow.

Subcaespitose; on dung and manured ground. Britain, France, Sweden, Hungary, Switzerland, United States.

70. Coprinus gonophyllus, Quél., I 4th Suppl. Jur. et Vosg., Ann. Sci. Nat. Bord. I884, pl. I, f. 2.

Pileus hemispherical, striate, blackish grey, shining, veil caducous, floccose, whitish, about $\mathbf{I} \cdot 5 \mathrm{~cm}$. broad; gills free, triangular, margin 
serrate; spores lemon-shaped, Io $\mu$ long; stem about $3 \mathrm{~cm}$. long, glabrous, slightly striate, white.

Ground in coal-yards. France.

71. Coprinus subglobatus, Berk. \& Curt., Proc. Amer. Acad. Arts. \& Sci. 1858 , p. I 18.

Pileus hemispherical, then expanding, almost even, pale brown, covered with a thick, whitish, downy veil, about $4-5 \mathrm{~cm}$. across; gills free, broad, white, then dusky purple; spores elliptical, 7-8 $\mu$ long; stem white, equal, slightly curved, hollow, smooth, $6-8 \mathrm{~cm}$. high.

On banks. California.

Distinguished among allies by the subglobose form of the pileus when young, and the thick veil.

72. Coprinus rubecula, B. \& Br., Linn. Soc. Journ. Vol. xi, p. 560 . (Fig. 40.)

Pileus broadly ovate, then campanulate, white, with a grey tinge, covered with acute chestnut-coloured scales when young, the margin becoming naked, very slightly striate, about $\mathbf{r} .5 \mathrm{~cm}$. high and wide; gills free; stem $2-3 \mathrm{~cm}$. high, white, smooth, hollow.

On decaying vegetable matter. Ceylon.

73. Coprinus arcuatus, Peck, 46th Rep. N. York State Mus. p. 27.

Pileus broadly ovate or subhemispherical, soon convex or campanulate, margin striate, white or greyish, darker with age, with small, white tomentose scales, $\mathbf{2 \cdot 5}-5 \mathrm{~cm}$. broad; gills broad, free; spores $7 \cdot 5-9 \times 5 \cdot 5-7.5 \mu$; stem $2.5-5 \mathrm{~cm}$. long, equal, white, glabrous, hollow.

Solitary or gregarious; on sandy soil recently overrun by fire. United States.

The mycelium binds the sand together into a globular mass. Scales of pileus easily separable, and soon disappear. Cystidia numerous, long.

74. Coprinus Spraguei, Berk. \& Curt., Ann. Nat. Hist., Oct. 1859, p. 292.

Pileus conical, then campanulate, tomentose, greyish, disc tawny, striate, up to $2 \mathrm{~cm}$. across; gills free, fere and distant; spores ellip- 
tical, slightly curved, $10 \times 5 \mu$; stem $3-5 \mathrm{~cm}$. high, smooth, pale reddish ochre.

On the ground. Cuba, United States, Britain.

Distinguished by the coloured stem.

75. Coprinus Spegazzinii, Karst., Ryssl., Finl. o. Skand. Hattsv. I, p. 550 .

Pileus very thin, cylindrical or oval, then expanding and splitting up to the disc, greyish, at first with a cobweb-like covering and even, soon naked and grooved, about $2 \mathrm{~cm}$. high and $3 \mathrm{~cm}$. across; gills free; spores $9^{-\mathrm{I}} 4 \times 5^{-6 \mu}$; stem about $7 \mathrm{~cm}$. long, white, hollow, thickened below and rooting, adpressedly silky.

On soil in a plant-pot. Finland.

76. Coprinus cubensis, B. \& C., Linn. Soc. Journ. (Bot.) Vol. x, p. 293.

Pileus conical, then conico-campanulate, covered with superficial, white, floccose scales, grey, even, $2-3.5 \mathrm{~cm}$. across; gills free, purplish brown; spores broadly oval or subglobose, $7 \times 5^{-6} \mu$; stem $2-3 \mathrm{~cm}$. long, base thickened.

Growing on logs. Cuba (Wright, No. 79).

Remarkable for the acutely campanulate pileus and the short stem.

77. Coprinus platypus, Berk., in Cke., Illustr. pl. 687 B.

Pileus campanulate, white, then yellowish, flocculose, $5 \mathrm{~mm}$. across ; gills free; spores $8 \times 6 \mu$; stem $\mathbf{I} \cdot 5-3 \mathrm{~cm}$. long, slender, base discoid.

On palm-stem in a conservatory. England.

Probably an extra-European species, introduced along with plants or soil.

78. Coprinus rotundosporus, Peck, 3ist Rep. State Mus. N. York, p. 34 .

Pileus campanulate, whitish or pale cinereous, with a thin floccose, subpersistent tomentum, even, about $2.5 \mathrm{~cm}$. across; gills free; spores subglobose, 8-9 $\mu$; stem white, slightly tapering upwards, $5^{-8} \mathrm{~cm}$. long.

About the roots of trees. United States.

This species is apparently related to $C$. niveus, and is remarkable for its nearly globose spores. 
79. Coprinus narcoticus, Fries, Epicr. p. 250.

Foetid. Cylindric-clavate, then expanded, greyish white, hyaline, striate, covered at first with white, floccose squamules, then naked, $\mathbf{I} \cdot 5^{-2} \mathrm{~cm}$. across ; gills free; spores I I $\times 5^{-6} \mu$; stem $4^{-5} \mathrm{~cm}$. long, white, downy at first, hollow.

In tufts on dung. Britain, Sweden, France, Germany, Switzerland.

Agrees with $C$. muralis in the strong smell, differs in the hyaline pileus and elliptical spores.

80. Coprinus muralis, Allesch. Sued-bayr. Pilze, p. 100.

Pileus membranaceous, smell strong, ammoniacal, cylindrical, then campanulate, striate, white, then grey, covered with white, floccose squamules, $2.5-3.5 \mathrm{~cm}$. high; gills free, narrow; spores subglobose, $6 \mu$ diameter; stem up to $\mathrm{I} 2 \mathrm{~cm}$. long, equal, hollow, floccosely squamose, then glabrous, pure white, somewhat shining, base densely fibrous.

On walls, \&c. Bavaria.

\section{Coprinus lagopus, Fries, Epicr. p. 250.}

Pileus cylindrical, then campanulate, coarsely striate up to the brown disc, remainder whitish, at first covered with white, flocculent down, then naked; $2 \cdot 5-5 \mathrm{~cm}$. across; gills free; spores $\mathrm{I} 4-\mathrm{I} 6 \times$ I0-1 $2 \mu$; stem IO-I $5 \mathrm{~cm}$. long, white, everywhere covered with white floccose down, hollow, fragile.

On dung, rotten wood, \&c. Britain, Sweden, France, Germany, Holland, Italy, Finland.

Distinguished from $C$. narcoticus by its smaller size and absence of smell, and from $C$. fimetarius in the down on the pileus not being in the form of squarrose scales. C. lagopides differs from the present in the tomentum breaking up into scales, and gills very distant from the stem.

82. Coprinus lagopides, Karst., Ryssl., Finl. o. Skand. Hattsv. I, p. 535. (Figs. 20-22.)

Pileus very thin, campanulate, sulcate, greyish, disc livid, ornamented with free white scales joined by hairs, $4-7 \mathrm{~cm}$. broad; gills 
distant from the stem, black; spores $6-8 \times 5^{-6} \mu$; stem up to $17 \mathrm{~cm}$. high, white, floccose, hollow.

On the ground among poplars. Finland.

Allied to C. lagopus.

83. Coprinus macrocephalus, Berk., Engl. Flora, Vol. v, p. I22.

Pileus cylindrical, then campanulate, margin slightly striate, ashy grey, disc brownish, sprinkled with pale, pointed scales, $2 \mathrm{~cm}$. high and broad; gills free; spores IIII $3 \times 7-8 \mu$; stem $3-5 \mathrm{~cm}$. long, dingy white, clothed with white fibrils, hollow.

Subcaespitose on rotten dung. Britain, France.

Allied to $C$. lagopus, but distinguished by the dark grey pileus, which is coarsely sulcate up to the umbo.

84. Coprinus tigrinellus, Boud., Bull. Soc. Bot. Fr. Vol. xxxii, p. 283 , pl. 9, f. 3. (Figs. 33-34.)

Pileus elliptic-oblong, then campanulate, striate, snow-white at first, margin becoming rosy-grey, pulverulent, with scattered tawny flecks upwards, about I cm. high and wide; gills free, white, then brownish black; spores broadly elliptical, tawny, I I $\times 7 \mu$; stem about $2 \mathrm{~cm}$. long, white, base slightly bulbous and often with blackish flecks.

On leaves of sedges, Iris, and other aquatic plants, growing just above water-level. France.

Closely allied to $C$. Friesii; differing in being covered at first with brown tomentum, which breaks up into flecks on pileus and base of stem.

85. Coprinus Friesii, Quélet, Champ. Jura, p. 129, pl. 23, fig. 5. (Figs. 37-38.)

Pileus elliptic-oblong, then expanding, floccosely pulverulent, delicately striate, white or apex tinged yellow, margin becoming rosygrey, $\mathbf{I - 2} \mathrm{cm}$. high and across; gills free, reddish, then black; spores angularly subglobose, about $10 \mu$ long; stem $2 \mathrm{~cm}$. long, slender, white, pulverulent, base rather swollen and floccose.

On dead grass and other leaves. France, Holland, Germany, Belgium, Finland.

Differs from $C$. tigrinellus, which also grows on grass, \&c., in not being covered when young with a brown veil. 
86. Coprinus cupulatus, E. Jacob., Mitteil. Brandenb. p. xxxi.

Pileus subcampanulate, covered at first with a floccose, greyish white veil, then pubescent, sulcate, apex depressed, greyish yellow, about 4-5 mm. high; gills free; spores $7-8 \times 6-7 \mu$; stem $5^{-7} \mathrm{~mm}$. high, white, downy, striate, base swollen into a small, slightly strigose bulb.

On dead twigs. Germany.

Allied to C. Friesii, C. tigrinellus, and C. Quéletii.

87. Coprinus fimetarius, Fries, Epicr. p. 245.

Pileus clavate, then conico-expanded, soon splitting, coarsely grooved, greyish, disc even and brownish, at first covered everywhere with squarrose, floccose scales, then naked, $2 \cdot 5^{-5} \mathrm{~cm}$. across; gills free; spores I $2-14 \times 7-8 \mu$; stem IO-I $5 \mathrm{~cm}$. long, white, squamulose, hollow, base thickened and solid.

On manure-heaps, \&c., solitary or most frequently clustered, soon becoming revolute and deliquescing.

Britain, Austria, Sweden, France, Switzerland, Germany, Siberia, Holland, Spain, Portugal, Italy, Russia, Belgium, Finland, Hungary, Australia, New Zealand.

Var. pullatus, Fries.

Pileus with adpressed squamules, soon naked, brown, then blackish, stem soon smooth. Stature of typical form.

Var. cinereus, Fries. (=Agaricus cinereus, Schaeff., Icon. tab. Ioo.)

Pileus floccosely mealy, then naked, grey; stem rootless, subequal, hollow to the base, often twisted. Size of typical form.

Var. macrorhiza, Fries. (Figs. I-2).

Pileus at first with feathery squamules, stem short, rooting. Paler and smaller than the typical form.

The above varieties grow on dung or rich soil, and appear good varieties in their extreme forms, but blend into the typical form and into each other.

88. Coprinus Quéletii, Schulzer, Hedw. I885, p. I 37.

Pileus ellipsoid-conical, then expanded, deeply sulcate, whitish; apex glabrous, tinged cinnamon, sprinkled with fugacious flecks, about $2.5 \mathrm{~cm}$. broad; gills free; spores elliptic-oblong, I O-I $2 \times 4-6 \mu$; 
stem up to $4 \mathrm{~cm}$. long, ventricose below, white, flocculose, then glabrous and silky; rooting, fibrils up to $2 \mathrm{~cm}$. long, brown.

On soil in plant-pots. Austria.

89. Coprinus laxus, Bresad. \& Schulz., Hedw. 1885, p. 136.

Pileus parabolic, then semiglobose, grey, disc yellowish cinnamon, granuloso-floccose, $\mathbf{I}-\mathbf{I} \cdot 2 \mathrm{~cm}$. broad; gills free, $2 \mathrm{~mm}$. broad; spores irregularly elliptical, black, $6-8 \times 4^{-5 \mu}$; stem $2.5^{-6.5} \mathrm{~cm}$. long, white, tinged brown at the slightly thickened base, with fugacious flecks, especially upwards.

In pastures. Austria.

The stem bends over as it dries.

90. Coprinus Albertinii, Karst., Hattsv. I, p. 53.5.

Pileus campanulate, sulcate, greyish white, disc brownish, clothed with a delicate network of fibrils, $3^{-4} \mathrm{~cm}$. broad; gills free, becoming distant from the stem; spores elliptical, opaque, ro-I $2 \times 6 \mu$; stem up to $7 \mathrm{~cm}$. long, silky flocculose, white.

Grassy places. Finland.

91. Coprinus plumbeus, Peck, 29th Rep. State Mus. N. York, p. 42.

Pileus thin, fragile, campanulate, deeply striate nearly to the apex, leaden grey, tawny on the small disc, sprinkled with tawny-cinereous hairs, $2 \cdot 5^{-4} \mathrm{~cm}$. across; gills free, narrow; spores elliptical, $10 \times 6 \mu$; stem 8-1 $2 \mathrm{~cm}$. high, white, floccose, hollow, slightly tapering upwards.

Paths in woods. United States.

92. Coprinus Strossmayeri, Schulzer, Verhandl. Zool. Bot. Gesell. Wien, Band 28, p. 430.

Pileus digitaliform, then conico-campanulate, whitish, then grey, apex darker, finally pale ochraceous, covered with superficial, seceding, squarrose scales, not striate, $5-8 \mathrm{~cm}$. broad; gills free; spores $7-9 \mu$ long; stem 4-16 cm. long, straight or ascending, white, delicately pruinose, hollow, springing from a blackish brown, compact, branching mycelium.

Subcaespitose at roots of trees. Austria. 
93. Coprinus tuberosus, Quél., Bull. Soc. Bot. France, Vol. xxiv, p. 289, pl. 3, fig. 2. (Figs. 26-30.)

Pileus elliptical, then campanulate, finely striate, white, then greyish, veil formed of hyaline vesicles, 3-5 $\mathrm{mm}$. high; gills blackish violet; spores elliptical, about I $2 \mu$ long; stem $2-4 \mathrm{~cm}$. long, very slender, rather flexuous, white, downy, springing from a small, black sclerotium.

On dung or decaying vegetable matter. France, England.

Somewhat resembling $C$. niveus, but smaller, and differing in springing from a sclerotium.

94. Coprinus cineratus, Quél., Bull. Soc. Bot. Fr. Vol. xxiii, p. 329, pl. 2, f. 7 .

Pileus cylindrical, then campanulate, striate, enveloped at first in a white, then greyish violet, volva formed of hyaline vesicles, dusky grey, $\mathrm{I}-2 \mathrm{~cm}$. high and broad; gills free, close to the stem; spores elliptical, I० $\times 5^{\mu}$; stem $4^{-6} \mathrm{~cm}$. high, white, base slightly swollen and sheathed by the remains of the volva.

Caespitose; on dung, \&c. France.

95. Coprinus filiformis, B. \& Br., Ann. \& Mag. Nat. Hist., Ser. 3, Vol. vii, p. 7, pl. I 5, fig. 8 .

Pileus cylindrical, grey, covered with white mealy particles, striate, I-2 mm. high; gills linear; spores subglobose, $5 \times 4 \mu$; stem I-I.5 mm. high, extremely slender, hyaline, sprinkled with short, delicate hairs.

On the ground in woods. England.

This minute species is not larger than Mucor caninus (B. and Br.).

96. Coprinus luxoviensis, Mont., Ann. Sci. Nat., Ser. 4, Vol. ix, p. I6I.

Pileus very delicate, ovoid, then campanulate, delicately striate, at first covered with white meal, then naked and grey, disc tawny; gills semilanceolate, distant; stem at first with spreading fibrils, soon naked, white, pellucid, $2.5 \mathrm{~cm}$. long, springing from a spreading mycelium.

On walls. France. 
97. Coprinus caducus, Harz., Bot. Centralb. xxvii, p. 4 I6.

Pileus oval, then cylindrical, striate, grey in the cylindrical state, then blackish brown, disk dark grey, at first covered with a dense snow-white powder, which becomes grey, 8-I I mm. high; gills springing from a collar; spores elliptical, $9-10 \times 6-7 \mu$; stem variable in length, 2-I $2 \mathrm{~cm}$. long, greyish brown above, base whitish.

In shaft of coal mine. Bavaria.

98. Coprinus Britzelmayri, Sacc. \& Cub., Syll. v, No. 4447 (Coprinus macrosporus, Britz., Melanosp. p. I83, f. I29; not of Peck).

Pileus and stem covered with snow-white meal; pileus $2 \mathrm{~cm}$. and more broad; gills adnexed, greyish black; spores elliptical, $20 \times 10-12 \mu$; stem up to $7 \mathrm{~cm}$. high by $5 \mathrm{~mm}$. thick.

In meadows. Bavaria.

99. Coprinus albulus, Quél., Assoc. France, Congrès de Rouen, $188_{3}$, p. 4, tab. 6, f. II.

Pileus almost hemispherical, pellucid, striate, minutely pulverulent, $5 \mathrm{~mm}$. broad; gills arcuately adnate; spores ovoid, $20 \mu$ long; stem $2 \mathrm{~cm}$. long, filiform, pulverulent, with a slender rooting base.

On fallen grass-stems (Triticum). France.

Resembling Mycena tenerrima in habit.

100. Coprinus semilanatus, Peck, 24th Rep. State Mus. N. York, p. 7 I.

Pileus broadly conical, then expanded, atomate, finely striate, pale greyish brown, $\mathbf{I} \cdot 5^{-2.5} \mathrm{~cm}$. broad; gills free; spores I $3 \mu$ long; stem IO-I $5 \mathrm{~cm}$. long, white lower half dotted with loose, cottony flecks, smooth or slightly mealy above, hollow.

On rich ground and dung. United States.

Very fragile. Allied to C. coöperius.

101. Coprinus divergens, Britz., Melan., p. 182, fig. 64 .

Pileus parabolic, brownish at first, margin paler, becoming dark grey, deeply striate, hoary at first, $\mathbf{I} \cdot 5 \mathrm{~cm}$. broad, gills blackish grey, spores elliptical, ends acute, Io-I I $\times 6-7 \mu$; stem up to $4 \mathrm{~cm}$. high, pellucid, whitish.

In pastures. Bavaria.

Intermediate between C. tomentosus and C. niveus (Britzelmayr). 


\section{SECTION V.}

102. Coprinus micaceus, Fries, Epicr. p. 247.

Pileus oval at first, then campanulate, margin plicate and irregular, striate, tawny ochraceous, at first covered with glistening micaceous particles, soon naked and becoming sulcate, 3-6 cm. across; gills adnexed; spores $7-8 \times 4-5 \mu$; stem $5^{-8} \mathrm{~cm}$. long, white, silky, hollow.

Usually densely clustered, at the base of old stumps, posts, \&c. Britain, France, Finland, Germany, Hungary, Siberia, Austria, Sweden, Holland, Spain, Portugal, Italy, Russia, Belgium, Switzerland, United States, Cape of Good Hope, Victoria.

At first densely covered with colourless micaceous particles; soon naked in rainy weather, when the pileus often becomes brownish. See remarks under $C$. truncorum.

103. Coprinus marcescens, Karst., Ryssl. Hattsv. I, p. 537.

Pileus campanulate, sulcate, whitish at first, soon dingy ochraceous, at length pale sooty-grey, disc brownish yellow, micaceous, sulcate, 3-4 cm. broad ; gills adnexed; spores obliquely elliptical, 6-9 $\times 4-6 \mu$; stem about $9 \mathrm{~cm}$. long, white, silky but even.

On the ground. Finland.

Allied to $C$. micaceus, but distinguished by the pileus becoming sooty-grey.

104. Coprinus aratus, B. \& Br., Brit. Fung., No. 927, Ann. Nat. Hist. (I 86I); emended, No. 1956.

Pileus narrowly elliptical, then campanulate, umber, deeply grooved up to the disc, sprinkled with large micaceous particles, $5-8 \mathrm{~cm}$. across; gills slightly adnexed, broadest behind; spores I $5 \times$ IO-I I $\mu$; stem I O-I $5 \mathrm{~cm}$. long, snow-white, silky, hollow.

In hollow trees, on the ground, \&c. Britain.

Berkeley and Broome at first described the present species as having free gills, and afterwards this was corrected to 'gills at first attached, but soon separating from the stem, but still connected at the base as if by a slight collar.' 
105. Coprinus stercorarius, Fries, Epicr. p. ${ }^{2} 5^{1}$.

Pileus ovate, then campanulate, margin striate, dersely covered with white glistening meal, $2 \cdot 5^{-3} \mathrm{~cm}$. high and broad; gills adnexed; spores I 4-I $5 \times 8 \mu$; stem $7-12 \mathrm{~cm}$ long, white, minutely mealy at first, hollow.

On dung, manured ground, \&c. Britain, Sweden, Belgium, Germany, France, Finland, Holland, Italy, Switzerland, Austria, Victoria, Queensland, Tasmania, New Zealand, United States.

Superficially resembles $C$. niveus, but the latter has the pileus covered with white, floccose down, not meal, and is altogether smaller.

C. albus, Quél., differs in having the disc more or less yellow, pileus sulcate, as is also the upper part of the stem.

106. Coprinus radians, Fries, Epicr. p. 248. (Figs. 6-8.)

Pileus ovate, then campanulate, glistening with micaceous particles, margin striate, disc granuloso-squamulose, tawny ochre, becoming pale, $2 \cdot 5^{-5} \mathrm{~cm}$. across; gills slightly adnexed; spores $7 \times 4 \mu$; stem 3-5 $\mathrm{cm}$. long, white, smooth, hollow, base with dense, radiating strands of mycelium.

On damp plastered walls. Britain, Franse, Sweden, Belgium, Finland.

Stem incurved from growing on a vertical surface, pileus becoming discoid.

\section{Coprinus truncorum, Fries, Epicr. p. 248.}

Pileus globose at first, then campanulate, densely covered with micaceous meal, soon naked, then tawny ochraceous, striate, not becoming sulcate, $2-4 \mathrm{~cm}$. across; gills free, rosy, then black; spores I 2-I $4 \times 6 \mu$; stem 7-10 cm. 1 n $\%$, slender, white, glabrous, hollow.

On rotten willows, \&c. Sweden, Britain, Holland, Germany, France, Switzerland, Belgium, Austria, Cape of Good Hope, Australia.

Allied to C. micaceus, but distinguished by the pileus being globose at first, never sulcate, and the free rosy gills.

108. Coprinus inamoenus, Karst., Grevillea, Vol. vii, p. 63 .

Foetid. Pileus subcylindrical, then expanded, blackish, densely covered with white micaceous scurf, even, $2-5 \mathrm{~cm}$. broad; gills 
attached to a collar remote from the stem; spores elliptical, 7-I I $\times 4-6 \mu$; stem 4-7 cm. long, often flexuous, hyaline-white, at first downy; several stems springing at intervals from a prostrate mycelium.

On heaps of rotten leaves. Finland.

109. Coprinus intermedius, Penzig, Ozonium et Copr. p. 140, pl. 3 and 4 .

Pileus cylindrical, then campanulate, pallid, even, at first densely covered towards the apex with reddish micaceous scurf, $3-3.5 \mathrm{~cm}$. broad; gills free, pinkish at first; spores elliptical, $7 \cdot 5-9 \times 5 \mu$; stem glabrous, tinged pink, 9-I I cm. long.

On damp wood, and on soil in flower-pots in hothouse. Italy.

Intermediate between $C$. stercorarius and $C$. coöpertus. Differs from former in cylindrical-not ovate-pileus, covered with rufescent -not white-micaceous scurf; from the latter in the glabrous stem.

110. Coprinus frustulosum, Sacc., Myc. Ven. Spec. p. 35, t. 6, f. IO-I4, from Atti della Soc. Ven.-Trent. Vol. ii.

Pileus ovate, then campanulate, rather acute, even, covered with reddish micaceous meal, up to $\mathrm{I} \mathrm{cm}$. high; gills free; spores $8 \times 6 \mu$; stem $\mathrm{I} \cdot 5 \mathrm{~cm}$. high, conical, then cylindrical, white, hollow, smooth.

On fragments of roots and twigs. Italy.

\section{Section VI.}

111. Coprinus conditus, Godey, in Gill. Champ. Fr. Hymen. p. 6I2.

Pileus globose, then ovoid, striate, white or tinged yellow, furfuraceous or slightly micaceous; gills adnate; stem $20-25 \mathrm{~mm}$. high when deliquescing, shining, furfuraceous.

In the interstices of cow-dung. France.

112. Coprinus nebulosus, Zoll., Flora, I847, p. 305.

White; pellucid; pileus with the disc granular when young, then splitting into greyish ridges, $\mathbf{I} \mathbf{- I} \cdot 5 \mathrm{~cm}$. across; gills linear; stem about $6 \mathrm{~cm}$. long, bulbous at the base.

On buffalo-dung. Java. 
113. Coprinus stellaris, Quél., Bull. Soc. Bot. France, Vol. xxiv, p. 322 , pl. 5 , fig. 6 .

Pileus ovoid, then campanulate, striate, snow-white then greyish, crovened with minute pellucid vesicles, $\mathrm{I}-2 \mathrm{~mm}$. across; gills adnate; spores elliptical, about $8 \mu$ long, stem I-2 $\mathrm{cm}$. long, filiform, hyaline, velvety with slender white hairs.

On dung of man, fox, \&c., in caves. France.

\section{Coprinus coöpertus, Fries, Epicr. p. 252.}

Pileus conico-campanulate, striate, lurid, yellowish grey when dry, densely covered with micaceous particles, up to $2.5 \mathrm{~cm}$. across; gills adnate, broad; stem 3-5 cm. long, pallid, apex with delicate white flecks.

On dung. Sweden, France, Italy, Hungary.

Somewhat caespitose ; very fragile.

115. Coprinus pseudo-plicatilis, Voglino, Rich. Anal. Agaric. p. 42 , t. 50 , f. 4 .

Pileus campanulate, umbonate, soon expanded and sulcate, yellowish grey, umbo yellowish, furfuraceous, $8-10 \mathrm{~mm}$. broad; gills adnate; spores $6-8 \times 3$, obliquely elliptical; stem $2.5-4 \mathrm{~cm}$. high, slender, woolly, white, thickened and floccose downwards.

On wood in a hothouse. Italy.

Springing from an Ozonium-like weft of ochraceous hyphae. Differs from $C$. plicatilis and $C$. sulcato-crenatus in the downy stem and absence of collar at apex of stem.

116. Coprinus aquatilis, Peck, 27th Rep. N. York State Mus. p. 96, pl. I, figs. 26-28.

Pileus campanulate, sulcate-plicate almost to the apex, scurfy, yellowish browen, $\mathbf{I} \cdot 5^{-2} \mathrm{~cm}$. across; gills reaching the stem, brownish, then black; spores $13 \times 8 \mu$; stem $5^{-7} \mathrm{~cm}$. high, slender, equal, hollow, whitish, scurfy.

On sticks or twigs partly submerged or lying in wet mossy places. United States.

The young plant is more yellow than the mature one. The species is related to $C$. silvaticus. 
117. Coprinus velox, Godey, in Gill. Champ. Fr. Hym. p. 6I4, with fig.

Pileus obovate, striate, then grooved, scurfy between the ribs, disc also greyish and scurfy, 3-4 $\mathrm{mm}$. across; gills close to the stem; stem $\mathrm{I} \cdot 5-3 \mathrm{~cm}$. long, covered with delicate white floccose down, base with radiating fibrils.

On cow-dung. France.

118. Coprinus ephemerus, Fries, Epicr. p. 25 2.

Pileus very delicate, ovate, then campanulate, sulcate, slightly scurfy at first, disc elevated, even, rufescent, $\mathbf{I}-2 \mathrm{~cm}$. across; gills slightly adnexed; spores $16-17 \times 9-10 \mu$; stem $3^{-6} \mathrm{~cm}$. long; glabrous, pellucid, whitish, holluw.

On dung-hills, manured ground, \&c. Britain, France, Denmark, Germany, Holland, Spain, Portugal, Sweden, Italy, Russia, Belgium, Finland, Hungary, Switzerland, United States, Queensland, New Zealand, South Africa.

Very slightly furfuraceous at first, soon naked.

119. Coprinus mycenopsis, Karsten, Symb. Myc. Fenn. viii, p. 8 .

Pileus campanulate, then expanded, sulcate, sooty-grey, the livid disc prominent, scurfy at first, soon naked, $3-7 \mathrm{~cm}$. across; gills adnate, purple, then brown; spores $7-8 \times 4 \mu$; stem up to $14 \mathrm{~cm}$. long, glabrous (apex very slightly flocculose), striate upwards, white, hollow.

In meadows. Finland.

120. Coprinus Berkeleyi, Montag., Syll. Pl. Crypt. No. 409, p. I3I.

Pileus cylindrical, ovate, then campanulate, delicately striate, furfuraceous, yellowish or greyish brown, then blackish, $3.5 \mathrm{~cm}$. high, $5 \mathrm{~cm}$. broad; gills adnexed, very narrow; stem up to $\mathrm{I}_{5} \mathrm{~cm}$. long, cartilaginous, variegated with yellowish green and rufous, hollow, glabrous, base thickened.

On rotten wood. United States.

Differs from C. stenophyllus in colour, absence of scales on pileus, and in having margin of pileus entire, and from $C$. deliquescens in the pileus being delicately striate and the adnexed gills. 
120*. Coprinus australiensis, Mass. (sp. nov.). (Figs. $3^{\mathrm{I}-32 .)}$

Pileus elliptical, soon becoming plane, finally upturned and umbonate, flesh very thin except at the disc, almost glabrous, pale tan, becoming greyish towards the margin, disc darker (when dry), striate, 5-7 cm. across when plane; gills free, broad, black, margin whitish, not readily deliquescing; spores lemon-shaped, black, I 7-1 $8 \times \mathbf{1 0 - 1 2} \mu$; stem IO-I $4 \mathrm{~cm}$. long, almost equal, whitish.

On dung. Brisbane, Queensland (Bailey, No. 69r).

A very distinct and beautiful species, at first referred to $C$. deliquescens, from which it differs in the much larger spores, and other points.

121. Coprinus cothurnatus, Godey, in Gillet's Champ. Fr. Hymen. p. 605, with fig.

Pileus conico-campanulate, finally expanded and umbonate, densely furfuraceous, dingy white, reddish, flesh-coloured, or yellowish, $2-3 \mathrm{~cm}$. across; gills free; spores elliptical; stem $3-5 \mathrm{~cm}$. long, white, squamulose beloze.

On cow-dung. France, Britain.

The strigose squamules surrounding the base of the stem represent a completely disintegrated volva.

122. Coprinus evanidus, Godey, in Gill. Champ. Fr. Hym. p. 6I4, with a fig.

Pileus obovate, then campanulate, striate, whitish, slightly furfuraceous, disc prominent, tinged broxen, 3-4 mm. across; gills free, distant; spores elliptical; stem $\mathbf{I} \cdot 5^{-2} \cdot 5 \mathrm{~cm}$. long, pellucid, white, covered with delicate white down.

In the interstices of cow-dung. France.

123. Coprinus sociatus, Fries, Epicr. p. 252.

Pileus ovate, then campanulate, plicate, subsquamulose or furfuraceous, pallid, disc umber, at length depressed, about $2 \mathrm{~cm}$. across; gills narrowed behind, attached to a collar, but not remote from the stem, blackish; stem $4-5 \mathrm{~cm}$. long, white, glabrous, not pellucid.

Damp ground in gardens, \&c. Denmark, Sweden, Britain, France, Germany, Holland, Belgium, Switzerland. 
Distinguished from $C$. plicatilis by the narrow collar, hence the gills are near to the stem, much narrowed behind, and black.

Fries describes a variety-Monogr. I, p. 468-having the collar obsolete, and the gills touching the stem.

124. Coprinus sulcato-crenatus, Steinhaus, in Sacc., Syll. v, No. 4492.

Pileus cylindrical, then campanulate, soon plane, sulcato-crenate, almost glabrous, yellow; disc brown, even, becoming depressed; gills remote from the stem, distant; spores laterally compressed, obtusely triangular; stem filiform, glabrous, yellow, apex brown.

On horse-dung. Poland.

Allied to $C$.plicatilis, differing in the yellow pileus and stem.

125. Coprinus Patouillardii, Quél., in Pat., Tab. Anal. Fung. p. 107, fig. 240.

Pileus conico-campanulate, then plane, coarsely striate up to the disc, ashy-grey, disc yellowish and rough with minute reddish granules or flecks, $\mathbf{I}-2 \mathrm{~cm}$. across; gills free, attached to a collar and distant from the stem; spores angularly globose, $6-8 \mu$ diameter; stem 4-7 cm. long, white, glabrous, fragile.

In clusters on remains of decayed grapes. France.

Distinguished from its close ally, C. nycthemerus, by the pure white stem and differently shaped spores. $C$. velaris differs in the glabrous pileus.

126. Coprinus papillatus, Fries, Epicr. p. 248.

Pileus elliptical, then campanulate, becoming plane or upturned, but the disc remaining prominent and rough with minute warts, striate, covered with a greyish scurf, disc darker, up to I cm. across; gills free; spores I $5 \times 7 \mu$; stem about $2.5 \mathrm{~cm}$. long, white, hyaline, hollow.

On the ground and on dung. Britain, Sweden, Germany, France, Russia, Belgium, Switzerland.

127. Coprinus Wrightii, Berk. \& Curt., Ann. \& Mag. Nat. Hist., I 859 , p. 10.

Pileus oval, then plane, striate, glaucous, scurfy, with small brown flecks, $\mathbf{I}-\mathbf{I} \cdot 5 \mathrm{~cm}$. across; gills free; spores obliquely elliptical, 
9-10 $\times 6 \mu$; stem $5 \mathrm{~cm}$. long, slender, whitish, smooth, pellucid, hollow.

On bits of grass, and in a flower-pot. United States.

128. Coprinus affinis, Karst., Ryssl., Finl. o. Skand. Hattsv. I, p. 536 .

Pileus very delicate, conico-cylindrical, then expanded, greyish white, disc pale rufous, plicate, scurfy, scarcely I cm. broad; gills free, narrow ; spores $6-8 \times 5-7 \mu$; stem about $3 \mathrm{~cm}$. long, slender, flaccid, glabrous, pallid.

On naked ground and on wood. Finland.

129. Coprinus curtus, Kalchbr., Grev. Vol. ix, p. I33.

Pileus cylindrical, then ovate campanulate, at first covered with rustcoloured scurf, then grey, sulcate, $6-8 \mathrm{~mm}$. high; gills free; stem $\mathbf{I}-\mathbf{I} \cdot 5 \mathrm{~cm}$. long, glabrous, hollow, base with white down.

On dung. South Africa.

Allied to $C$. plicatilis, but smaller and scurfy.

130. Coprinus radiatus, Fries, Epicr. p. $25 \mathrm{I}$.

Pileus cylindrical, then campanulate; soon plane, sulcate and splitting, at first with greyish scurf, yellowish, disc tawny, 3-4 $\mathrm{mm}$. across; gills free; spores $7-8 \times 5 \mu$; stem $\mathrm{I}-2 \mathrm{~cm}$. high, hyaline, nearly glabrous, whitish.

On horse-dung, often on the underside or in the interstices. Britain, France, Germany, Holland, Spain, Portugal, Sweden, Italy, Russia, Belgium, Finland, Switzerland, Cape of Good Hope, United States.

Distinguished by its minute size, and the plane, radiately fissured pileus.

131. Coprinus lanatus, Bong., in Weinm. Ross. p. 279.

Pileus soon campanulate, plicately striate, greyish rufous, disc darker, $\mathbf{I} \cdot 5^{-2} \cdot 5 \mathrm{~cm}$. high; gills free, purplish brown; stem slightly bulbous, glabrous, white, $2 \cdot 5-5 \mathrm{~cm}$. long.

Under hedges, \&c. Russia.

Solitary; fugacious.

132. Coprinus tardus, Karst., Symb. Ad. Myc. Fenn. vi, p. 20.

Pileus ovoid, then campanulate, coarsely striate, bay, then paler, glabrous, $2 \cdot 5-5 \mathrm{~cm}$. high and broad; gills adnate; spores angularly 
ovoid, 1 2-1 $8 \times 7-9 \mu$; stem 6-1 $0 \mathrm{~cm}$. high, sometimes slightly flexuous, equal, white, pulverulent.

Caespitose ; on naked ground. Finland, England, Hungary.

Smell none; differing from $C$. deliquescens in the smooth-not papillose-disc, and in the pileus not becoming upturned, and adnate, crowded gills.

133. Coprinus mutatinus, Mont., Cent. vii, p. 30.

Entirely grey; pileus very delicate, at first conico-convex, soon plane, very glabrous, slightly striate, margin crenulate; gills slightly adnated, very narrow; stem puberulous, fistulose.

On dung. Brazil.

134. Coprinus sclerotigenus, Ellis \& Everh., The Microscope, I 890, p. I 29, with fig. (Figs. 26-28.)

Pileus ovoid or ovoid-oblong, then campanulate, blackish brown, apex tinged whitish, about I $\mathrm{cm}$. high and broad; gills adnexed; spores obliquely elliptical, $8-10 \times 5^{-6} \mu$; stem $2 \cdot 5^{-10} \mathrm{~cm}$. high, slender, subequal, usually straight upwards and more or less flexuous below, where it is also downy, springing from an irregularly subglobose, rugulose, sclerotium, which is black externally, inside white.

On sheep's dung. United States.

135. Coprinus auricomis, Pat., Tab. Anal. Fung. p. 200, fig. 453. (Figs. I 5-I 9.)

Pileus elliptic-oblong, then campanulate, finely striate, pale greyish red, disc darker, glabrous, $\mathbf{I} \cdot 5^{-2} \mathrm{~cm}$. high and broad; gills adnate; spores ochraceous brown, elliptical; stem $5^{-8} \mathrm{~cm}$. high, white, glabrous.

Clustered, on rotten wood. France.

Young plants enveloped in a golden-yellow Ozonium, some of the filaments remaining on the pileus and base of stem at maturity.

136. Coprinus pachyterus, B. \& Br., Linn. Soc. Journ. (Bot.), Vol. xi, p. $5^{6}$ I.

Pileus persistently campanulate, plicato-sulcate, smooth, $5 \mathrm{~cm}$. across; gills arcuate, adnexed; spores elliptical, $\mathbf{1} 4-\mathbf{I} 5 \times 7-8 \mu$; stem $6-8 \mathrm{~cm}$. long, white, smooth.

On the ground. Ceylon.

Allied to $C$.plicatilis, but larger. 
137. Coprinus congregatus, Fries, Epicr. p. 249.

Pileus cylindrical, then campanulate, margin slightly striate, glabrous, viscid, ochraceous, $\mathbf{r} \cdot 5^{-2} \mathrm{~cm}$. high; gills slightly adnexed; stem $2-3 \mathrm{~cm}$. high, smooth, hollow, white.

On the ground, also in hot-houses. Sweden, Britain, France, Germany, Spain, Portugal, Belgium, Finland, Hungary.

Distinguished by the entirely ochraceous, glabrous, viscid pileus. Densely tufted.

138. Coprinus silvaticus, Peck, 24th Rep. N. York State Mus. p. 7I, pl. 4, figs. IO-I 4 .

Pileus convex, striate half-way up from the margin, dark brown, the furrowes paler, $\mathbf{I} \cdot 5^{-2} \mathrm{~cm}$. across; gills attached to the stem, brownish; spores gibbous-ovate, I $2-\mathbf{I} 3 \mu$ long; stem $5 \mathrm{~cm}$. high, fragile, hollow, smooth, slender, white.

On the ground in woods. United States.

Allied to $C$. plicatilis and $C$. ephemeris.

139. Coprinus alternatus, Fries, Epicr. p. 248.

Pileus hemispherical, then discoid, even, quite glabrous, chalk-white, disc pale umber, $3 \mathrm{~cm}$. broad; gills adnate; spores $10 \times 6-7 \mu$; stem whitish, smooth, hollow, 7-10 $\mathrm{cm}$. long.

In small clusters on the ground. Britain, Denmark.

140. Coprinus angulatus, Peck, 26th Rep. N. York State Mus. p. 60.

Pileus hemispherical, plicate-sulcate, disc smooth, $\mathbf{I} \cdot 5^{-2} \cdot 5 \mathrm{~cm}$. across ; gills reaching the stem, white, then blackish; spores compressed, angular, subovate, Iо $\times 9 \mu$; stem equal, smooth, whitish, 3-5 $\mathrm{cm}$. long.

In woods. United States.

141. Coprinus digitalis, Fries, Epicr. p. 249.

Pileus ovate, then campanulate, whitish, disc darker, quite glabrous, striate up to the disc, $2.5 \mathrm{~cm}$. high and broad; gills slightly adnexed; stem $3^{-10} \mathrm{~cm}$. long, equal, rather flexuous, glabrous, white.

On the ground in woods. Sweden, Denmark, Britain, France, Germany, Holland, Italy, Finland.

Tufted; fragile. When mature the pileus is livid-olive or yellowish grey, and the gills appear to be adnate. 
142. Coprinus hortensis, Mont., Syll. P1. Crypt. No. 406, p. I3I.

Pileus very delicate, silvery-grey, convex, then campanulate, at length expanded, glabrous, finely striate up to the even disc, $3.5 \mathrm{~cm}$. broad; gills slightly adnexed, very narrow; stem $4 \mathrm{~cm}$. long, even, glabrous.

On the ground. Cayenne.

143. Coprinus diaphanus, Quél., Bull. Soc. Bot. France, Vol. xxiv, pl. 5, fig. 7 .

Every part translucent and glabrous; pileus grooved, margin crenulate, silvery with a central tawny spot, 6-8 $\mathrm{mm}$. broad; gills adnate ; spores elliptical, г $2 \mu$ long; stem capillary, hyaline, glabrous, $2-3 \mathrm{~cm}$. long.

Grassy places in woods, \&c. France.

Distinguished from small specimens of $C$. plicatilis by the adnate gills.

144. Coprinus sceptrum, Fries, Epicr. p. 253.

Pileus campanulate, papillately umbonate, deeply sulcate, pellucid, tinged grey, 5-7 mm. broad; gills adnate to a collar; spores black; stem $2 \cdot 5-5 \mathrm{~cm}$. long, pellucid.

Rich ground among grass. Germany, France, Sweden.

145. Coprinus erythrocephalus, Fries, Hym. Eur. p. 327.

Pıleus cylindrical, then campanulate, silky and shining, margin very finely striate, reddish vermilion, becoming grey, about $\mathbf{I} \mathrm{cm}$. high and broad; gills slightly adnexed; stem $2-3 \mathrm{~cm}$. high, red, paler than the pileus.

Caespitose; on soil mixed with powdered gypsum. France.

Readily distinguished by the red pileus and stem.

146. Coprinus Godeyi, Gillet, Champ. Fr. Hym. p. 6I I, with fig.

Pileus ovoid-globose, distantly grooved, very glabrous, pellucid, disc ochraceous, grey between the ribs, 3-4 $\mathrm{mm}$. diameter; gills free; spores elliptical; stem about $2 \mathrm{~cm}$. long, pellucid, sprinkled with white fecks below.

On soil in plant-pots. France. 


\section{Genus Coprinus.}

147. Coprinus semistriatus, Pat., Tab. Anal. Fung. p. I94, fig. 435. (Figs. 9-I 2.)

Pileus ovate, then campanulate, glabrous, disc even, yellowish, from margin up to disc grey and striate; about $\mathbf{I ~} \mathrm{cm}$. high; gills attached to a collar; spores almost circular, compressed, $\mathbf{I} 2-\mathbf{I} 4 \times 3 \mu$; stem I-2 cm. long, white, pruinose, base pilose.

Tufted or scattered; on manured ground, \&c. France.

148. Coprinus consobrinus, Mont., Cent. vii, p. 30.

White; pileus pellucid, centre sometimes tinged yellow, smooth, shining, striate, margin denticulate; gills free and distant from the stem, very narrow ; stem tall, floccosely squamulose.

Solitary or gregarious. Brazil.

149. Coprinus plicatilis, Fries, Epicr. p. 252. (Figs. 23-25.)

Pileus very delicate, cylindric-ovate, then campanulate, soon plane, coarsely grooved, glabrous, pale brown, then greyish, disc broad, even, at length depressed, darker, $\mathrm{I}-2 \mathrm{~cm}$. across ; gills free, attached to a collar, distant from the stem; spores II I-I $3 \times 8-9 \mu$; stem $5^{-8} \mathrm{~cm}$. long, white, smooth, hollow.

On the ground among grass, \&c. Switzerland, Britain, Sweden, Italy, Russia, Belgium, Finland, Hungary, Denmark, Germany, France, Holland, United States, South Africa, E. Tropical Africa, Ceylon, Queensland, New Zealand, Behring Straits, India, Japan.

There is a trace of scurf, especially in the grooves of the pileus when young.

150. Coprinis mirabilis, Mont., Syll. Pl. Crypt. No. 407, p. I3I.

Pileus very delicate, soon plane and radiately sulcate, margin crenulate, white; gills free; spores globose; stem slender, hollow, white.

On the ground under trees. Cayenne.

151. Coprinus deliquescens, Fries, Epicr. p. 249.

Pileus ovate, then campanulate, finally expanded, livid grey; disc rufescent, papillose, otherwise glabrous, 3-7 cm. across, often rather wavy; gills free ; spores $8 \times 5 \mu$; stem $7-10 \mathrm{~cm}$. long, white, glabrous, hollow. 
On trunks, stumps, heaps of leaves, \&c. Holland, Spain, Portugal, Russia, Belgium, Finland, Britain, Sweden, France, Germany, Hungary, Switzerland, Queensland.

Slightly tufted. Differs from $C$. atramentarius in the free gills, distant from the stem, and in being altogether more slender.

152. Coprinus flosculus, Berk., Flor. Antart. p. 448, tab. clxii, fig. 2.

Pileus ovate, sulcate, apex depressed, glabrous, greyish, margin crenulate, $3 \mathrm{~mm}$. high, $2 \mathrm{~mm}$. broad, gills free; spores ovate; stem $4 \mathrm{~mm}$. high.

On dung. Berkeley Sound, Falkland Island.

It resembles in habit $C$. Hendersonii, Fr., but differs in the absence of a ring.

153. Coprinus miser, Karsten, Ryssl., Finl. o. Skand. Hattsv. 2, p. 236.

Pileus subglobose, then expanded, pellucid, tinged grey, plicate, glabrous, I-2 mm. broad; gills distant from stem, few in number; spores broadly elliptical, $7-9 \times 6-8 \mu$; stem $\mathbf{I}-2 \mathrm{~cm}$. long, slender, hyaline, glabrous.

On horse-dung. Finland.

154. Coprinus eburneus, Quél., Assoc. France, I 883, p. 4, tab. vi, fig. Io.

Entirely white, shining; elliptic-campanulate, firm, striate, rarely with a few scattered flecks, $3-4 \mathrm{~cm}$. broad; gills free; spores ovate, I $4 \mu$ long ; stem firm, glabrous.

On the ground in upland regions. France.

Allied to C. exstinctorius; resembling Psathyra gyroflexa in habit.

155. Coprinus hemerobius, Fries, Episc. p. 253.

Pileus ovate, then campanulate, coarsely grooved, disc even, bay, not depressed, $\mathbf{I} \cdot 5^{-2} \cdot 5 \mathrm{~cm}$. across; gills attached to a very slightly developed collar; stem $5^{-8} \mathrm{~cm}$. high, very fragile, pallid; spores elliptical, г O-I $2 \times 7 \mu$.

Among grass on roadsides, \&c. Sweden, Britain, Germany, Holland, Denmark, France, Italy, Finland.

Differs from $C$. velaris in the imperfect collar at apex of stem, and in the pileus being ovate when young. $C$. plicatilis differs in having the disc depressed at maturity. 
156. Coprinus rapidus, Fries, Epicr. p. 253.

Pileus cylindrical, then plane, coarsely grooved, lurid or pale drab, always glabrous, often slightly undulated, $\mathbf{I} \cdot 5^{-2} \cdot 5 \mathrm{~cm}$. across; gills free but close to the stem, brown; stem $4-5 \mathrm{~cm}$. high, white, glabrous.

On the ground near dwellings, \&c. Sweden, France, Germany.

Deliquescing rapidly after expansion.

157. Coprinus modestus, Berk. \& Curt., Proc. Amer. Acad. Arts \& Sci. I858, p. I I 8.

Pileus very delicate, sulcate, glabrous, pallid purple; gills linear, free, black; stem slender.

On decayed wood. Bonin Islands.

There is no specimen in Berkeley's herbarium, hence the original meagre description cannot be supplemented.

Species belonging to the last division with a glabrous pileus, but cannot be arranged in the series, owing to absence of information respecting the attachment of the gills. $-47-54$.

158. Coprinus sororius, Karsten, Symb. Myc. Fenn. viii, p. 9 .

Pileus naked (from the first?), about $2 \mathrm{~cm}$. broad; gills white or greyish, then black; spores $9-\mathbf{I} 2 \times 6-7 \mu$; stem $5^{-6} \mathrm{~cm}$. long, even, obsoletely focculose, hyaline-white, pellucid.

In meadows. Finland.

Similar to C. mycenopsis, but smaller (Karsten).

159. Coprinus plutonius, Mont., Hist. Nat. Iles Canar. p. 72, pl. 5, Fig. 2.

Pileus conico-campanulate, white, costate, ribs joined by transverse bars, margin crenate, disc umbonate, even, yellowish, $2-3 \mathrm{~cm}$. across when expanded; gills distant, black; stem 4-6 cm. long, hollow, base incrassated, white with numerous blackish bands at regular intervals.

Gregarious on volcanic scoriae. Gomera, Canary Islands.

160. Coprinus spiralis, Mont., Hist. Nat.'Iles Canar. p. 72, pl. 4 , fig. 5 .

Pileus conico-campanulate, acuminate, margin sulcate for a short distance, ochraceous brown, up to $1 \mathrm{~cm}$. high; gills greyish black; 
stem 2-3 cm. high, slender, spirally twisted and very flexuous, dark coloured.

On fallen branches in damp places. Canary Islands.

Resembling Psathyra gyroflexa in habit. Springing from a dense black mycelium.

161. Coprinus pilulifer, Mont., Hist. Nat. Iles Canar. p. 72, pl. 4, Fig. 6.

Pileus globose, margin minutely toothed, greyish, pellucid, striate up to the minute, even disc, 4-6 mm. across; gills black; stem $2-3 \mathrm{~cm}$. high, white, naked, very fragile, hollow.

Sandy ground. Canary Islands.

162. Coprinus phyllophilus, Karsten, Ryssl. Hattsv. I, p. 544 .

Pileus campanulate, then expanded, glabrous, sulcate, pale, dingy ochraceous, becoming sooty, about $\mathbf{I} \cdot 5 \mathrm{~cm}$. across; gills close to the stem; spores elliptical, IO-I $3 \times 5^{-7 \mu}$; stem about $6 \mathrm{~cm}$. long, pruinose, then naked, hyaline, pellucid.

Among fallen leaves. Finland.

163. Coprinus velaris, Fries, Epicr. p. 2.53.

Pileus at first globose, then hemispherical, coarsely striate, lurid, disc brownish, not depressed, up to $2.5 \mathrm{~cm}$. high and wide; gills becoming black, edge white; spores angularly ovate, $7-8 \times 5 \mu$; stem $5-7 \mathrm{~cm}$. long, pellucid, base downy.

On manured ground in gardens, \&c. Sweden, Germany, France.

164. Coprinus pellucidus, Karsten, Symb. Myc. Fenn. x, p. 6r, in Mem. Soc. Fauna et Flora Finl. ( 1883 ).

Pileus obovate, then hemispherical, obtuse, sulcate, glabrous, whitish or yellowish, then hyaline and greyish with a darker central spot, I-2 mm. broad; gills crowded; spores ellipsoid, $7-9 \times 4 \mu$; stem I.5 cm. long, flexuous, glabrous, pellucid.

On cow-dung. Finland.

Closely allied to $C$. diaphanus, Quél.

165. Coprinus Schroteri, Karsten, Ryssl. Hattsvampar, I, p. 345 .

Pileus elliptical, then expanded, sulcate, glabrous, dingy ochraceous, becoming pale, at length sooty-grey, up to I cm. broad; gills brown; 
spores angularly subglobose, $\mathbf{I} 3-\mathbf{I} 5 \times 8-\mathbf{I} 2 \mu$; stem $\mathbf{I}-\mathbf{2} \mathrm{cm}$. long, slightly striate upwards, minutely pulverulent at first.

On cow-dung. Finland.

Solitary. Allied to C. Boudieri.

Var. proximellus, Mass. (Coprinus proximellus, Karst., Hattsv. I, p. 544).

Spores elliptical, I0-1 $3 \times 5^{-7} \mu$; otherwise as in type form.

Manured ground, \&c. Finland.

Four species, received during the progress of the work, are in duplicate numbers, signified by an asterisk (*), thus making a total of $\mathrm{I} 69$ species.

\section{Species Imperfectly Described.}

Coprinus marculentus, Britz., Hym. Sudb. ix, p. I3. Coprinus pseudo-nycthemerus, Britz., Hym. Sudb. ix, p. I3.

Coprinus Filholi, Fourc., Rev. Mycol. I, p. 66.

\section{EXCLUDED SPECIES.}

Coprinus pulchrifolius, Peck, 29th Report N. York State Mus. p. 4 I. Gills cinnamon, then brown at maturity, and not deliquescent, exclude this species from the genus Coprimus, and at the same time suggest the genus Bolbitius.

Coprinus Lamottei, Gill., Champ. France, p. 603.

The gills remaining dry, and the brown spores are not in accordance with the conception of the genus Coprinus.

Coprimus solifugus, March., in Fries, Hym. Eur. p. 333 .

Excluded on account of the yellowish somewhat decurrent gills.

Coprinus setulosus, B. and Br., Journ. Linn. Soc. Vol. xi, p. $5^{6}$ r.

The type-specimens are immature, and the gills white, hence there is no evidence that the species is a Coprinus. The name should be entirely dropped. 


\section{NDEX.}

\section{Coprinus, I 39.}

affinis, $\mathrm{p} .173$.

Albertinii, I63.

albulus, 165 .

albus, I 53 .

alopecia, I 55 .

alternatus, I 75 .

angulatus, I 75 .

apthosus, I 50 .

aquatilis, I69.

aratus, 166.

arcuatus, I 58.

armillaris, I 44 .

atramentarius, I43.

auricomis, I 74 .

australiensis, I $7 \mathrm{I}$.

Barbeyi, I 47 .

Berkeleyi, I 7o.

Boudieri, ${ }_{5} 6$.

Brassicae, I 54 .

Bresadolae, I45.

Britzelmayri, I65.

bulbillosus, I 45 .

Burmandii, I 54 .

caducus, $16_{5}$.

cineratus, $16_{4}$.

cinereus, $\mathrm{I} 62$.

clavatus, $\mathbf{1} 42$.

Colensoi, I 5 2.

comatus, I 42.

- var. clavatus, $\mathbf{I}^{2}$.

- ovatus, I 42.

conditus, $\mathbf{I} 68$.

congregatus, I 75 .

consobrinus, I 77 .

coöpertus, I 69 .

cothurnatus, I 7 I.

cubensis, I 59 .

cupulatus, $\mathrm{I} 62$.

curtus, I 73 .

cyclodes, I4I.

cylindricus, I 48 .

deliquescens, 177 .

diaphanus, 176 .

digitalis, 175 .

dilectus, I 4 I. discipes, 156 .

divergens, ${ }^{6}{ }_{5}$.

domesticus, I 55 .

ebulbosus, I 50 .

eburneus, I 78 .

ephemeroides, I 45.

- var. muscorum, I45.

ephemerus, I 70.

equinus, I 4 I.

erythrocephalus, 176 .

evanidus, I 7 I.

exstinctorius, I 53 .

fibrillosus, ${ }_{4} 8$.

Filholi, I8I.

filiformis, 164 .

fimbriatus, I53.

fimetarius, 162 .

- var. cinereus, $\mathbf{I} 62$.

- - macrorhiza, I62.

- - pullatus, I62.

flocculosus, I 49.

flosculus, I 78 .

Forquignoni, I5 I.

Friesii, I6r.

frustulosum, 168.

fuscescens, 146 .

gigasporus, 157 .

Godeyi, 176 .

gonophyllus, I 57 .

hemerobius, $\mathrm{I} 78$.

Hendersonii, I44.

hortensis, I 76 .

imbricatus, 146.

inamoenus, 167 .

insignis, 146.

intermedius, I 68 .

jasmundianus, $\mathbf{I} 4 \mathrm{O}$.

lagopides, I6o.

lagopus, 160 .

Lamottei, I8I.

lanatus, I 73 .

laniger, I 55 . laxus, 163 .

Lerchenfeldii, 147 .

luxoviensis, $16_{4}$.

macrocephalus, I6I.

macropus, $\mathrm{I}_{57}$.

macrosporus, I 49.

macrosporus, 165.

marcescens, I66.

marculentus, I8I.

Mayrii, I48.

micaceus, 166.

microsporus, I 49 .

mirabilis, $\mathbf{I} 77$.

miser, $\mathrm{I} 78$.

modestus, I79.

muralis, I6o.

murinus, ${ }_{54}$.

muscorum, I 45 .

musicola, I 47 .

mutatinus, I 74 .

mycenopsis, I 70 .

narcoticus, 160 .

nebulosus, I68.

niveus, $\mathbf{I}_{52}$.

- var. astroideus, $\mathbf{I}_{52}$.

nycthemerus, $\mathrm{I} 57$.

oblectus, I 40.

ovatus, $\mathrm{I}^{2}$.

pachypterus, I 74 .

panormitanus, I 42 .

papillatus, $\mathbf{I} 72$.

Patouillardii, I 72.

pauci-lamellatus, I47.

pellucidus, I8o.

phaeosporus, I 5 o.

phyllophilus, I 80.

picaceus, I 50.

pilosus, I 53 .

pilulifer, I80.

platypus, I 59 .

plicatilis, I 77 .

plumbeus, 163 .

plutonius, I 79 .

praegnans, I 44 .

proximellus, I8I. 


\section{Genus Coprinus.}

pseudo-nycthemerus, $\mathrm{I} 8 \mathrm{r}$. pseudo-plicatilis, I69. pulchrifolius, I8I. punctatus, I 48 . pyrenaeus, I43.

Quéletii, I62. Quéletii, I5I.

radians, 167 . radiatus, $\mathrm{I} 73$. rapidus, $\mathrm{I} 79$. roris, I 53 . rotundosporus, I 59. rubecula, ${ }_{5} 8$.

saatensis, $14^{8 .}$ scauroides, 145 . sceptrum, I 76 . Schröteri, I 80. - var. proximellus, I8I. sclerotigenus, I74. semilanatus, $\mathrm{I}_{5}$. semistriatus, 177 . setulosus, I $8 \mathrm{I}$.

Seymouri, I 56 . silvaticus, $I 75$. similis, I 54 . soboliferus, I 43 . sociatus, I $7 \mathrm{I}$. solifugus, $\mathrm{I} 8 \mathrm{I}$. solstitialis, I 39 . sororius, I 79 . Spegazzinii, I 59 . spiralis, I79. Spraguei, I $5^{8}$. stellaris, I69. stenocoleus, I 40. stenophyllus, I 49 . stercorarius, 167 . sterquilinus, I 39 . Strossmayeri, I63.

subcoeruleo-griseus, I 56 . Wrightii, I72. subglobatus, I 58 . sulcato-crenatus, I 72.

tardus, I 73 .

tergiversans, I 47 .

tigrinellus, г6 6 .

tomentosus, I 5 I.

torquatus, $\mathrm{I} 45$.

Trappenii, I4I.

tuberosus, 164 .

truncorum, 167 .

umbrinus, I 40.

varicus, $\mathrm{I} 52$.

variegatus, I 44 .

velaris, I80.

velatus, I 5 I

velox, $\mathrm{I} 70$.

virgineus, I 57 .

volvaceo-minimus, I 4 I.

\section{EXPLANATION OF FIGURES IN PLATES $\mathrm{X}$ AND XI.}

Illustrating Mr. Massee's paper on Coprinus.

Fig. I. Coprinus fimetarius, var. macrorhiza, Fr. Fungus nat. size.

Fig. 2. Basidium with spores of same. $\times 400$.

Fig. 3. Coprinus gigasporus, Massee; nat. size.

Fig. 4. Section through pileus of same; nat. size.

Fig. 5. Basidium with spores of same. $\times 500$.

Fig. 6. Coprinus radians, Fr., group of plants, showing the radiating mycelium ; nat. size.

Fig. 7. Section through pileus of same; nat. size.

Fig. 8. Basidium with spores of same. $\times 400$.

Fig. 9. Coprinus semistriatus, Pat., group of plants ; nat. size.

Fig. 10. Section of same; nat. size.

Fig. II. Section through a portion of the hymenium of the same, showing basidia bearing spores, also a cystidium. $\times 500$.

Fig. I2. Spores of same; the spores are lentil-shaped; one of the figures shows the surface of a spore, the other one the edge. $\times 500$ (after Patouillard).

Fig. I3. Coprinus umbrinus, Massee; $a$, the plant in a young stage of development, as yet completely enclosed in its white universal veil, which is beginning to crack, owing to the expansion of the pileus; $b$, fully developed plant; the universal veil remains in part as a volva with a free, drooping margin, sheathing the base of the stem, and partly as a central cap, and in the form of torn patches, on the surface of the pileus ; nat. size. 


\section{Massee.-A Revision of the Genus Coprimus.}

Fig. I4. Section through pileus of same; nat. size.

Fig. I 5. Coprinus auricomus, Pat., cluster of plants ; nat. size.

Fig. I6. Section of same; nat. size.

Fig. I7. Portion of hymenium of same, showing a basidium and a cystidium. $\times 500$.

Fig. 18. Spores of same. $\times 500$.

Fig. I9. Portion of surface of pileus of same, showing a projecting filament of Ozonium. $\quad \times 500$ (after Patouillard).

Fig. 20. Coprinus lagopides, Karsten; nat. size.

Fig. 2I. Section of same species; nat. size.

Fig. 22. Spores of same; highly mag. (after Karsten).

Fig 23. Coprimus plicatilis, Fr., plant; nat. size.

Fig. 24. Section of same; nat. size.

Fig. 25. Section through portion of pileus and gills of same, showing the thin flesh of the pileus continuous, at $a$; at $b, b^{\prime}$, the flesh of the pileus is broken, due to the splitting of the gills down the line of the trama, the flesh of the pileus forming scurfy or furfuraceous lines along the crests of the gills at $b, b^{\prime} . \times 100$.

Fig. 26. Coprinus sclerotigenus, Ellis and Everh., group of Fungi springing from a sclerotium, $a$; nat. size.

Fig. 27. Section of same; $a$, sclerotium; nat. size.

Fig. 28. Spores of same. $\times 400$ (after Ellis).

Fig. 29. Coprinus tuberosus, Quélet, springing from a sclerotium, $a$; nat. size.

Fig. 30 . Spores of same. $\times 400$.

Fig. 31. Coprinus australiensis, Massee; nat. size.

Fig. 32 . Spores of same. $\times 400$.

Fig. 33. Coprinus tigrinellus, Boudier; nat. size.

Fig. 34 . Spores of same. $\times 400$.

Fig. 35. Coprimus punctatus, Kalchbr.; nat. size.

Fig. 36. Section of same; nat. size.

Fig. 37. Coprinus Friesii, Quélet; nat. size.

Fig. 38. Spores of same. $\times 400$.

Fig. 39. Coprinus microsporus, B. \& Br.; nat. size.

Fig. 40. Coprinus rubecula, B. \& Br.; nat. size.

Fig. 4I. Coprinus macropus, B. \& Br. ; nat. size. 


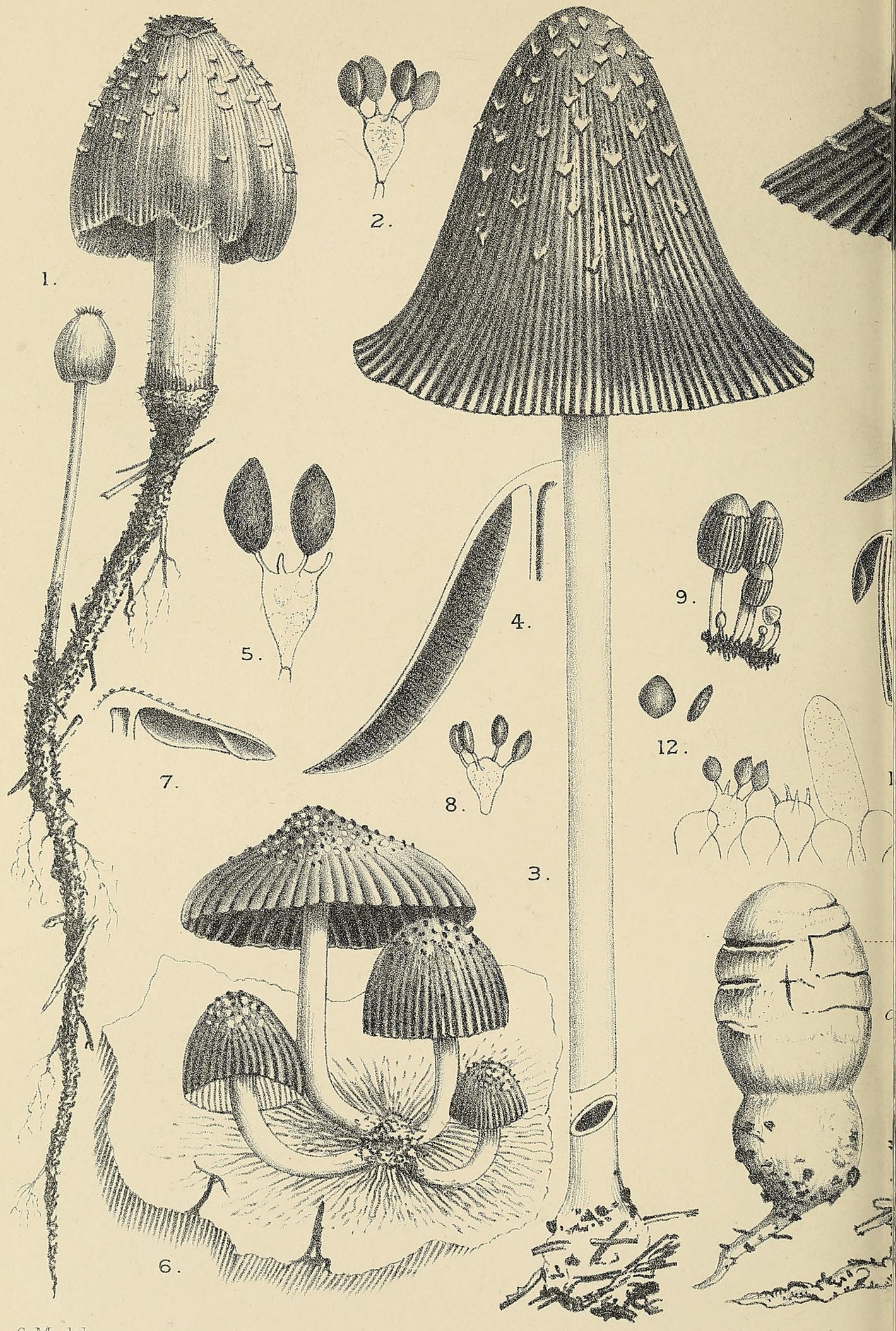


Vol.X, PL.X.

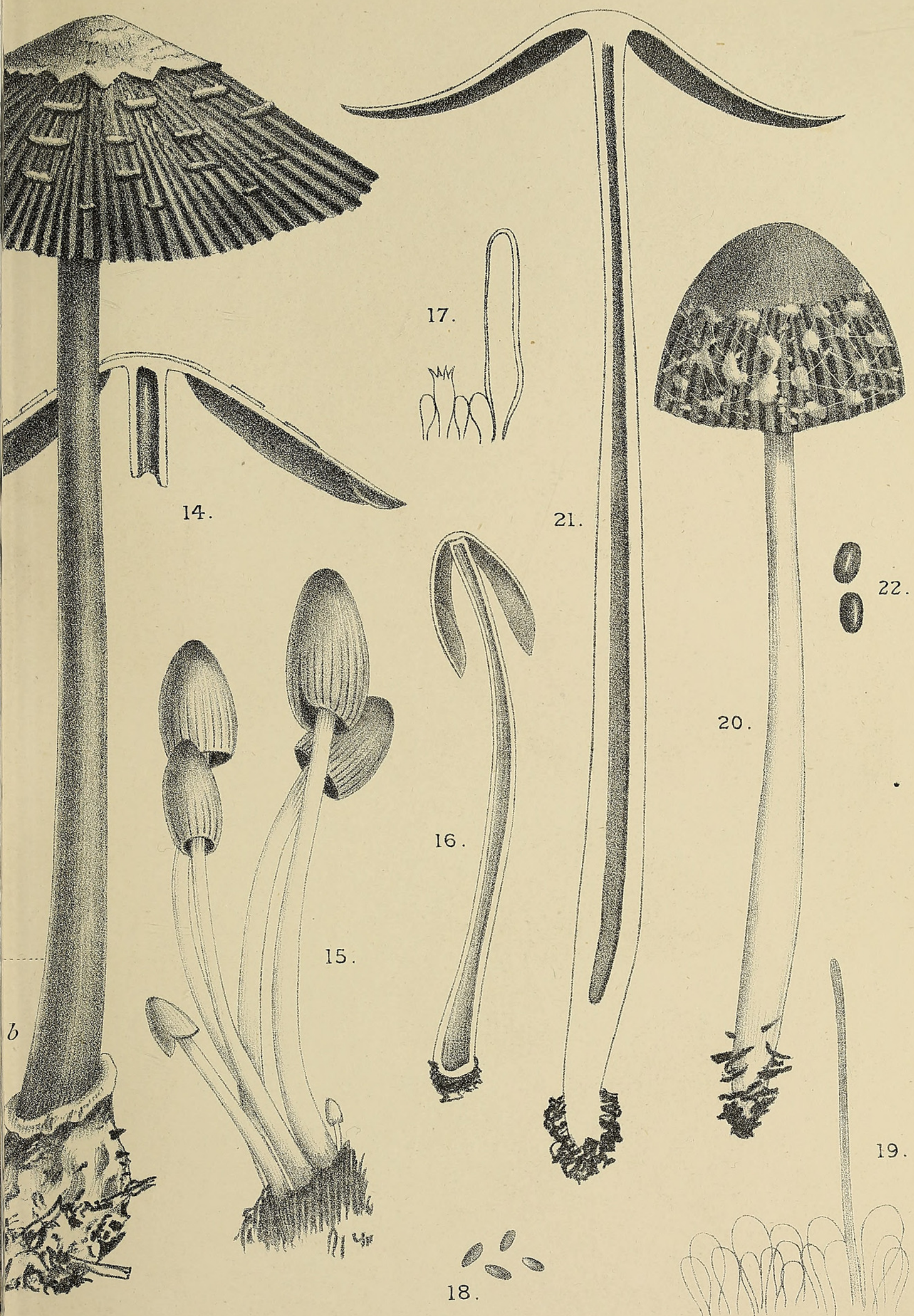




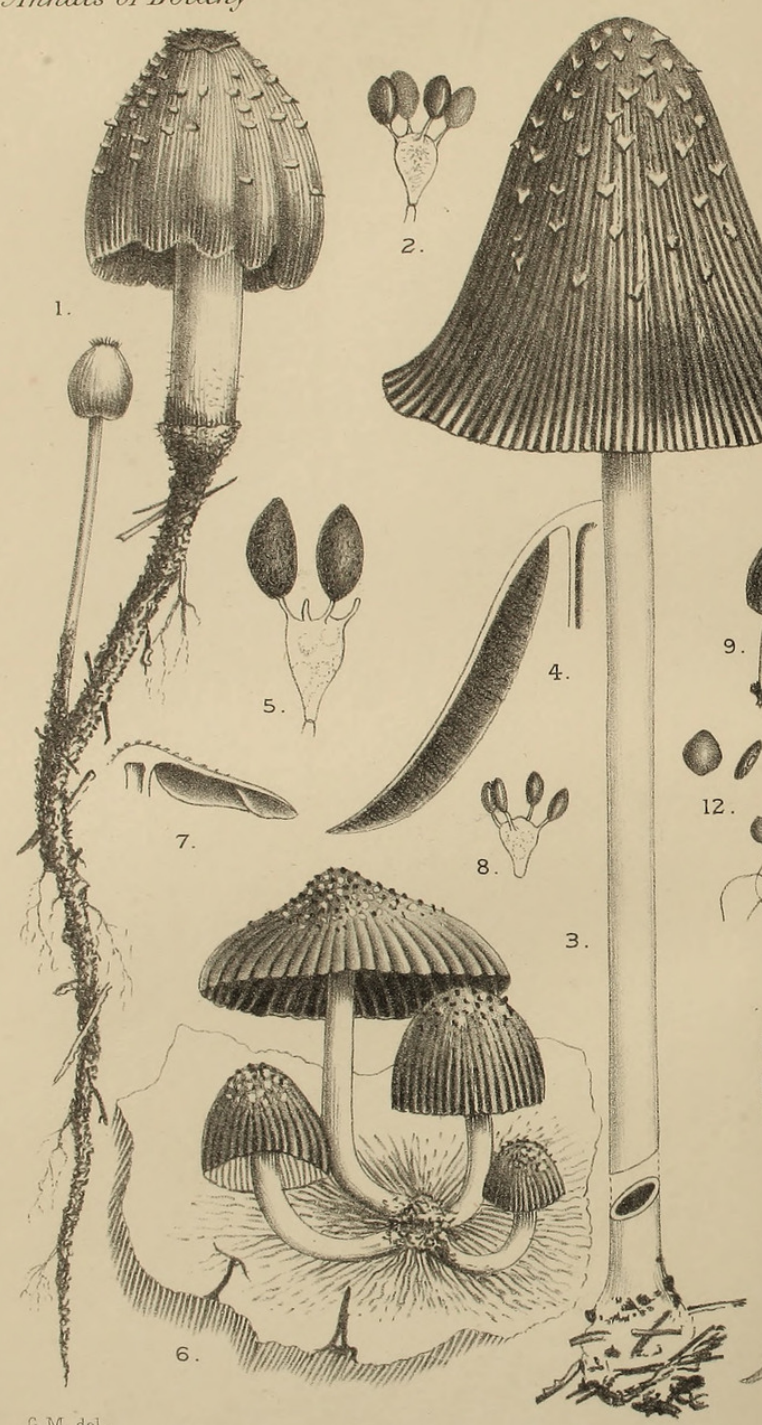

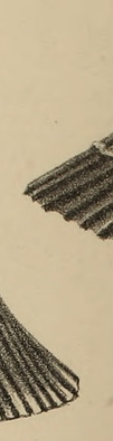
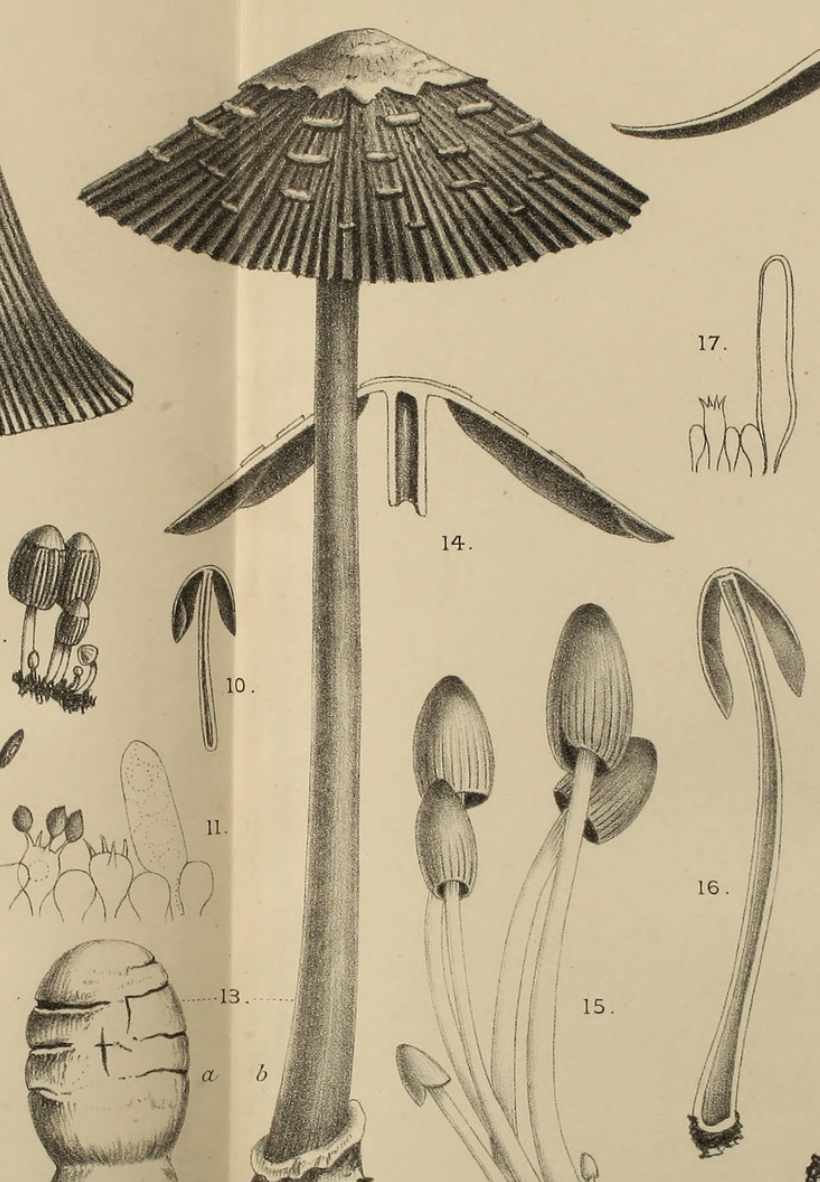

M
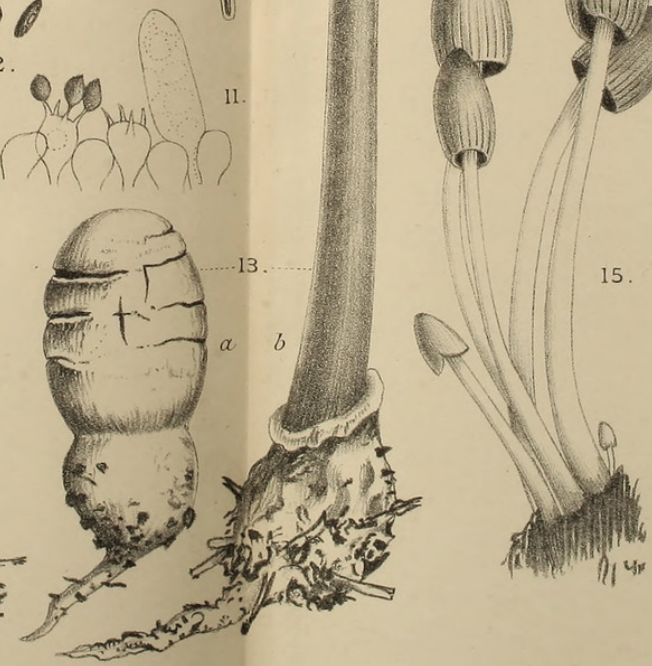

MASSEE. - COPRINUS

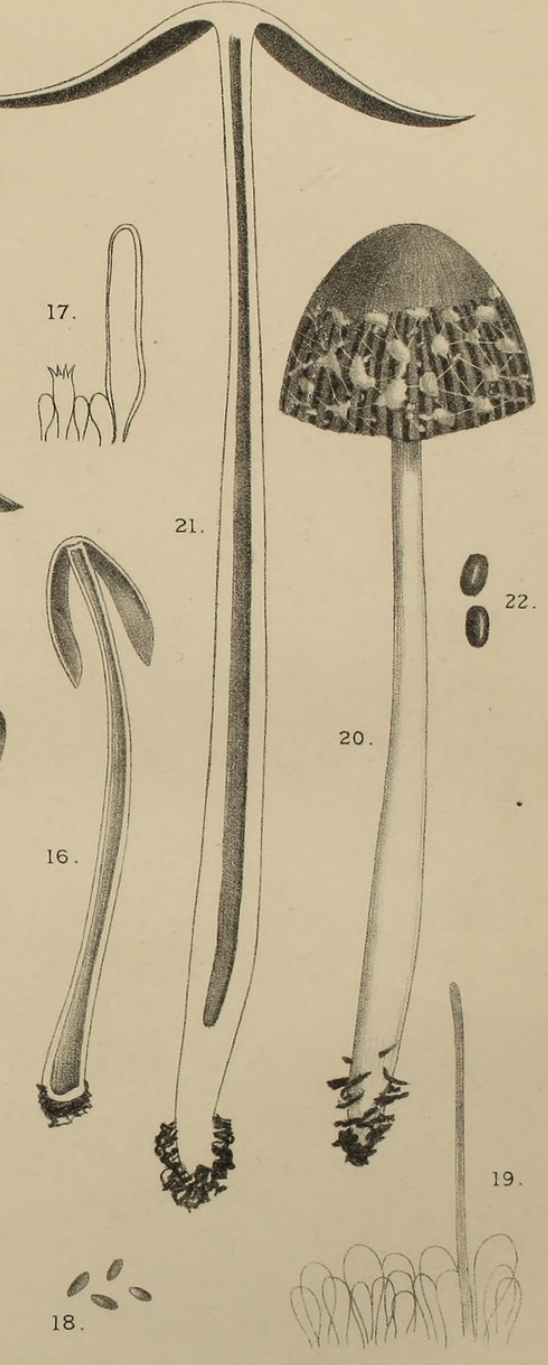

University Press, 0xford 


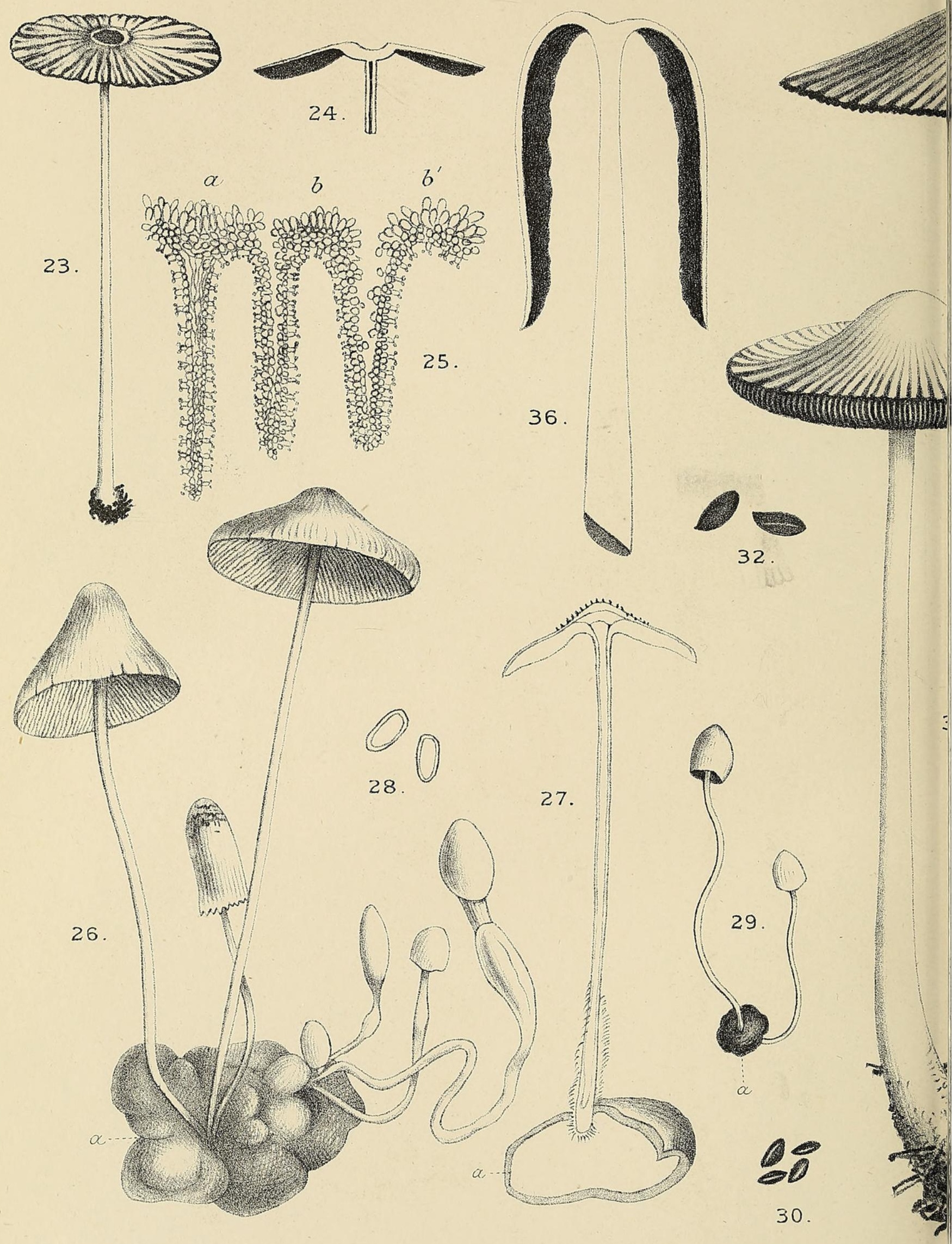


Vol.X,PL.XI.

\section{(n)}

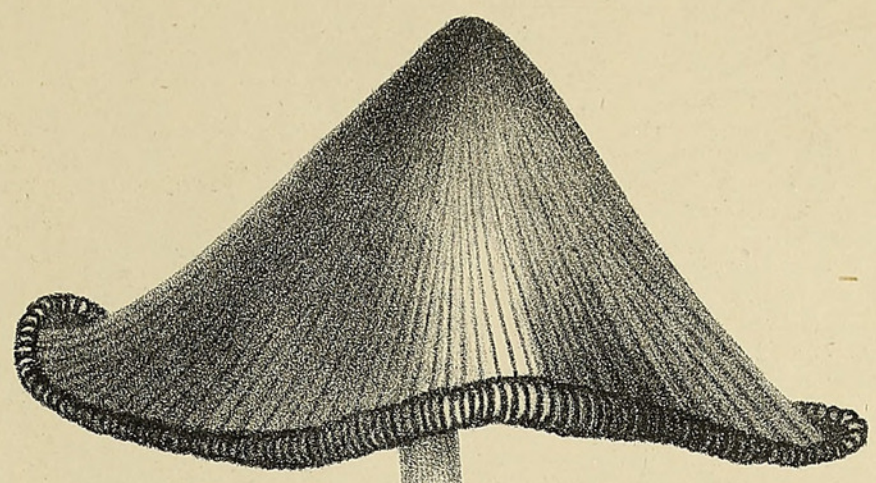

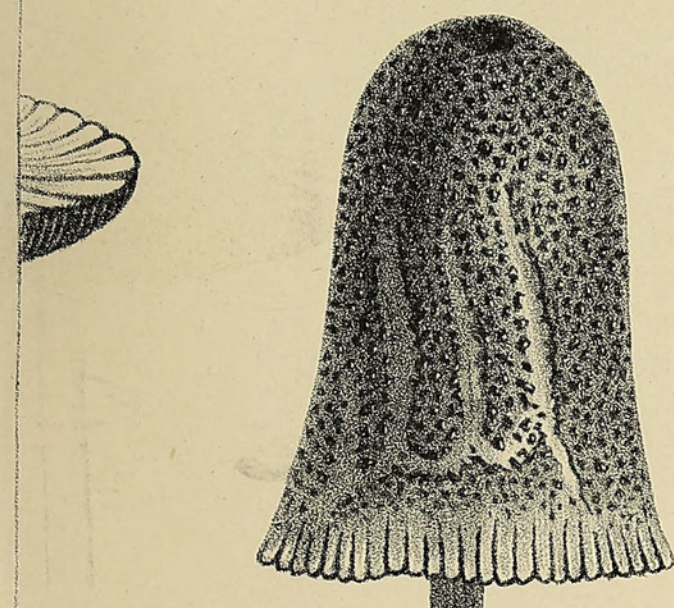
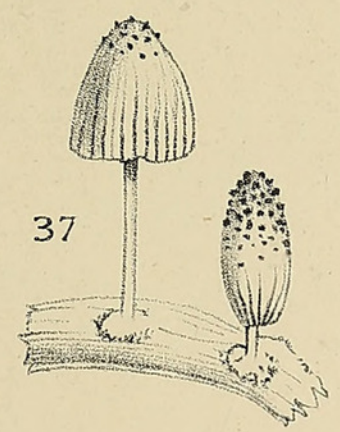

0

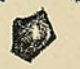

38

39.

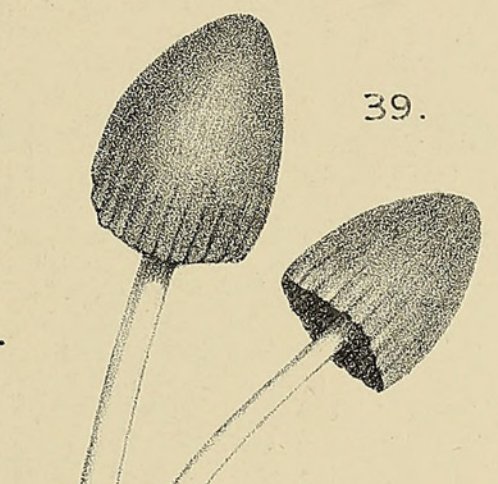

33.

:0

34.
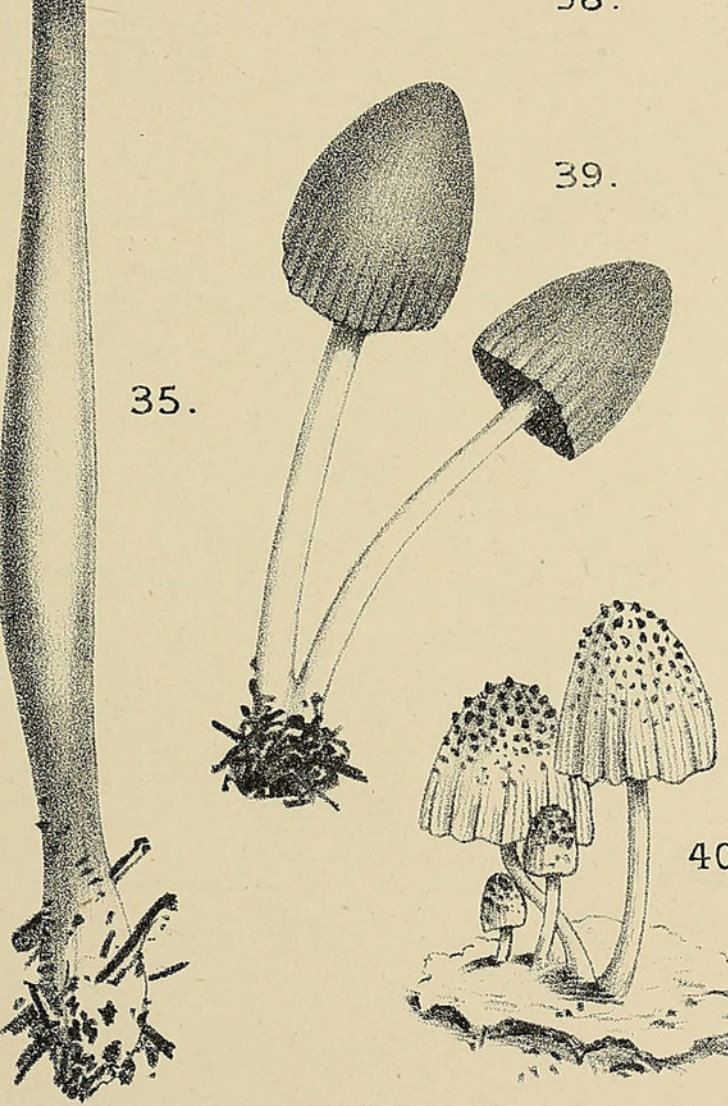
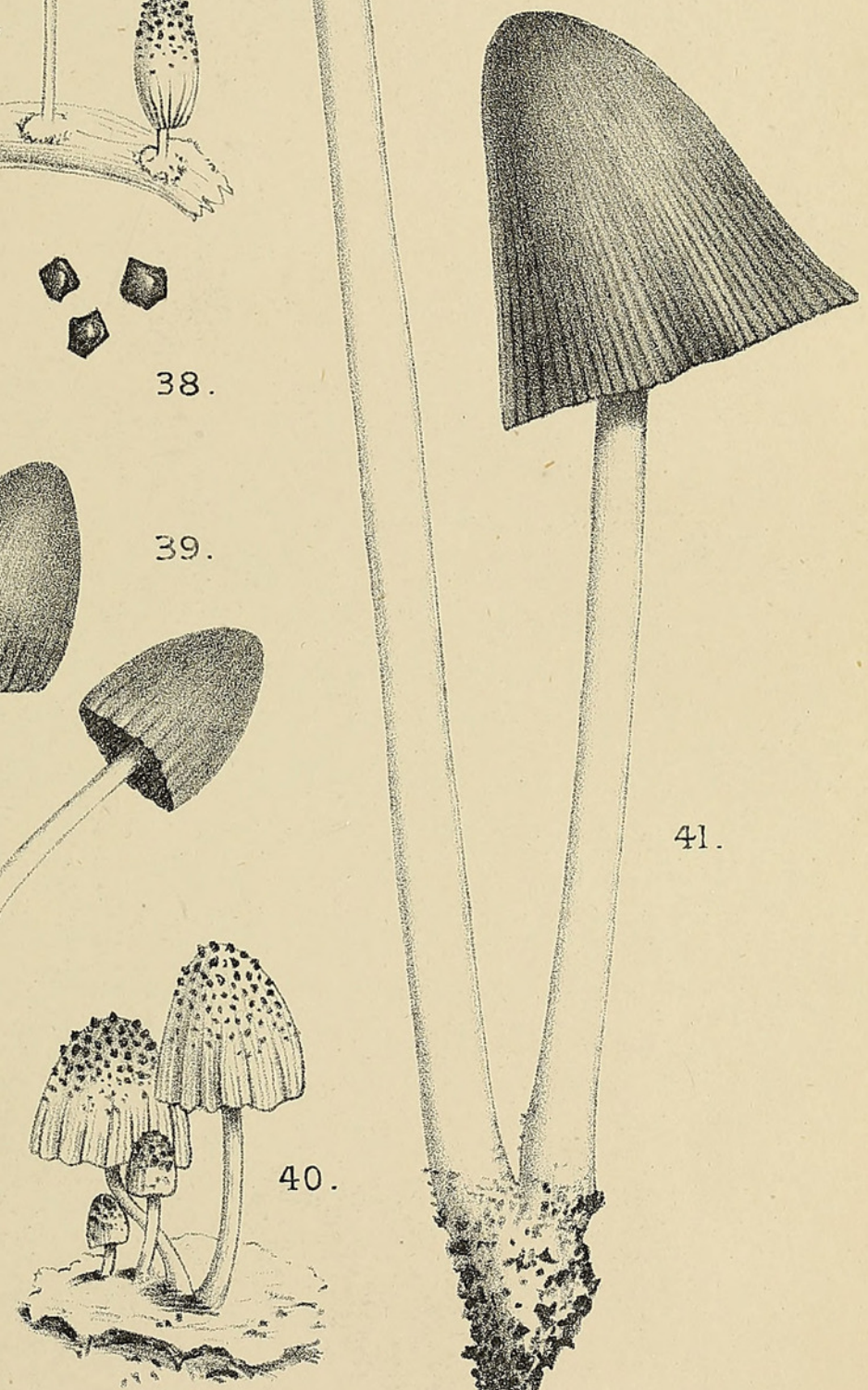


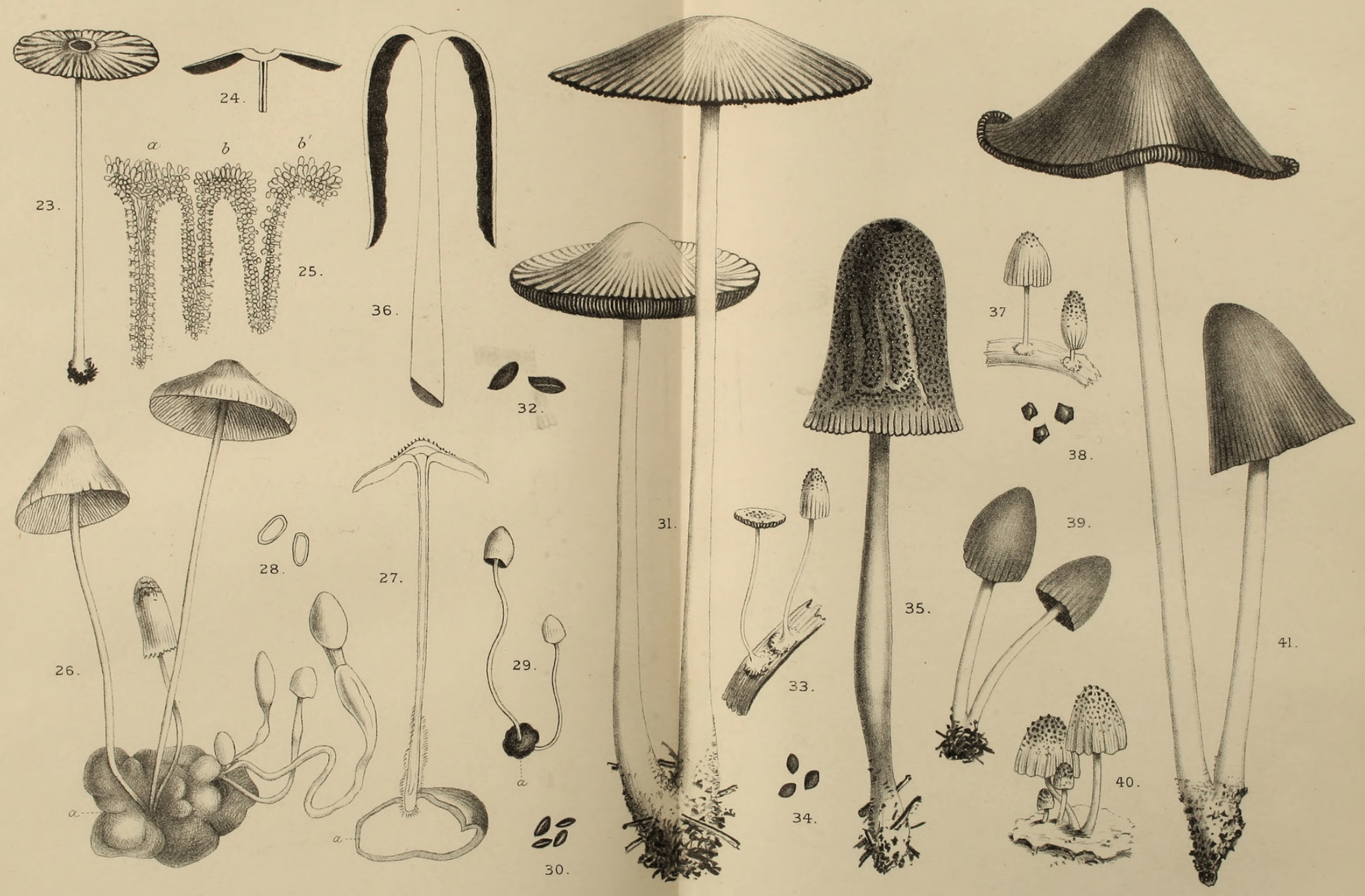




\section{$2 \mathrm{BHL}$ Biodiversity Heritage Library}

Massee, George. 1896. "A revision of the genus Coprinus." Annals of botany 10, 123-184. https://doi.org/10.1093/oxfordjournals.aob.a088607.

View This Item Online: https://www.biodiversitylibrary.org/item/235772

DOI: https://doi.org/10.1093/oxfordjournals.aob.a088607

Permalink: https://www.biodiversitylibrary.org/partpdf/318419

\section{Holding Institution}

Smithsonian Libraries

\section{Sponsored by}

Biodiversity Heritage Library

\section{Copyright \& Reuse}

Copyright Status: Not in copyright. The BHL knows of no copyright restrictions on this item.

This document was created from content at the Biodiversity Heritage Library, the world's largest open access digital library for biodiversity literature and archives. Visit BHL at https://www.biodiversitylibrary.org. 